\title{
Geochemical characteristics and depositional environments of the Narimba Formation source rock, Bass Basin, Australia
}

\author{
Mohamed Ragab Shalaby ${ }^{1,2}$ - Muhammad Izzat Izzuddin bin Haji Irwan ${ }^{1} \cdot$ Liyana Nadiah Osli $^{1} \cdot$ Md Aminul Islam $^{1}$
}

Received: 6 July 2020 / Accepted: 24 August 2020 / Published online: 3 September 2020

(C) The Author(s) 2020

\begin{abstract}
This research aims to conduct source rock characterization on the Narimba Formation in the Bass Basin, Australia, which is made of mostly sandstone, shale and coal. The geochemical characteristics and depositional environments have been investigated through a variety of data such as rock-eval pyrolysis, TOC, organic petrography and biomarkers. Total organic carbon (TOC) values indicated good to excellent organic richness with values ranging from 1.1 to $79.2 \%$. Kerogen typing of the examined samples from the Narimba Formation indicates that the formation contains organic matter capable of generating kerogen Type-III, Type-II-III and Type-II which is gas prone, oil-gas prone and oil prone, respectively. Pyrolysis maturity parameters (Tmax, PI), in combination with vitrinite reflectance and some biomarkers, all confirm that all samples are at early mature to mature and are in the oil and wet gas windows. The biomarkers data (the isoprenoids $(\mathrm{Pr} / \mathrm{Ph}), \mathrm{CPI}$, isoprenoids/n-alkanes distribution $\left(\mathrm{Pr} / \mathrm{nC}_{17}\right.$ and $\left.\mathrm{Ph} / \mathrm{nC}_{18}\right)$, in addition to the regular sterane biomarkers $\left(\mathrm{C}_{27}, \mathrm{C}_{28}\right.$ and $\left.\mathrm{C}_{29}\right)$ are mainly used to evaluate the paleodepositional environment, maturity and biodegradation. It has been interpreted that the Narimba Formation was found to be deposited in non-marine (oxygen-rich) depositional environment with a dominance of terrestrial plant sources. All the analyzed samples show clear indication to be considered at the early mature to mature oil window with some indication of biodegradation.
\end{abstract}

Keywords Narimba Formation $\cdot$ Source rock characterization $\cdot$ Petroleum system $\cdot$ Bass Basin

\section{Introduction}

The Bass Basin is located to the southeast of Australia. It is a rift basin underlying the Bass Strait which runs between Victoria and Tasmania (Fig. 1). It had been formed during the Early Cretaceous to recent, trending northwest-southeast (Blevin et al. 2003; Boreham et al. 2003). It is dominantly offshore and has a total extent of $42,000 \mathrm{~km}^{2}$, bounded to the west by the King Island High and northwest and by Flinders Island and the Bassian Rise to the northeast (Fig. 1) (Blevin, et al. 2003; Boreham et al. 2003; Cummings et al. 2004). The basin is divided into the Cape Wickham and Durroon sub-basins (Fig. 1). The Bass Basin is a portion of the larger Southern Rift System that separated Australia

Mohamed Ragab Shalaby

mshalaby2004@yahoo.com

1 Department of Geosciences, Universiti Brunei Darussalam, Jalan Tungku Link, Gadong BE1410, Brunei Darussalam

2 Geology Department, Faculty of Science, Tanta University, Tanta 31527, Egypt and Antarctica from the Late Jurassic to Early Cretaceous (Etheridge et al. 1985a, 1985b; Boreham et al. 2003).

Several geochemical analyses had shown that the hydrocarbon in the Bass Basin is mainly originated from land-plant material with little to no indication of marine origin (Edwards et al. 1999). It has been suggested that liquid hydrocarbons are produced from organic matter disseminated in carbonaceous claystones, while natural gas originated mostly from coaly facies (Nicholas et al. 1981; Miyazaki 1995). However, Blevin et al. (2003) and Boreham et al. (2003) had found that tertiary coals (aged Middle to Early Eocene) were responsible for generating the liquid hydrocarbons. The pattern of hydrocarbon distribution suggests that hydrocarbons had been generated and accumulated in the Cormorant, Yolla and Pelican troughs in Bass Basin. The generated hydrocarbons migrated to traps within the troughs or adjacent structures. More than 30 wells had been drilled since 1965 with a drilling density of approximately one well per $1320 \mathrm{~km}^{2}$ (Blevin et al. 2003). Previous exploration had discovered hydrocarbons 
Fig. 1 Map showing the extent of the Bass Basin, highlighting the studied wells (modified after Boreham et al. 2003)

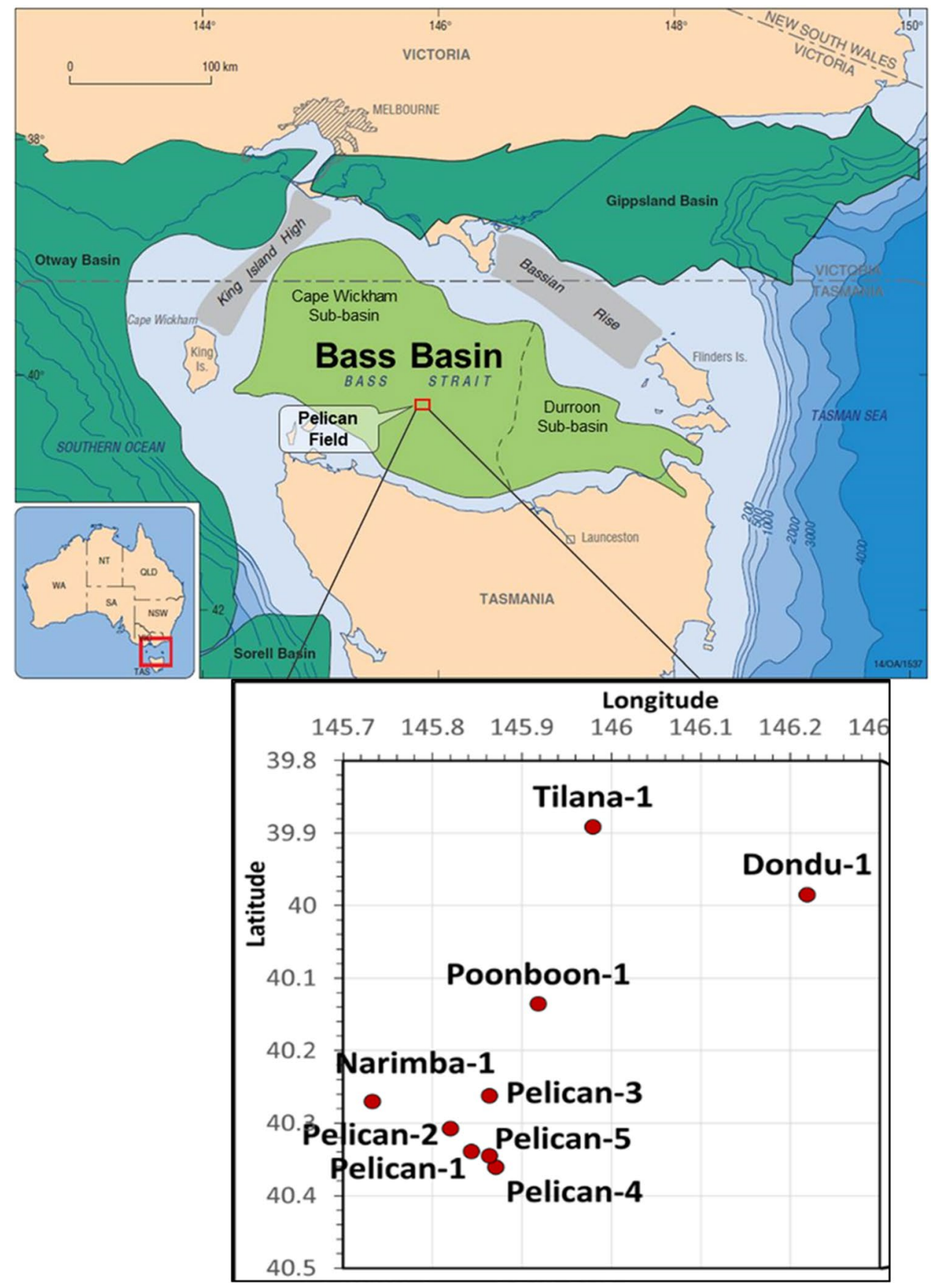

at the fields named Pelican, Cormorant, Yolla, Trefoil and White Ibis (Blevin et al. 2003; Arian 2010).

The interbedded coals and fluvio-deltaic as well as lacustrine shales are considered the dominant source rocks in the basin (Partridge 2002) where the Bass Basin contains significant amounts of these source rocks (Partridge 2002). The Narimba Formation is being part of the Middle Eastern View Group. It is comprised of interbedded coals, thin shale beds and sandstone (Blevin et al. 2005). This formation has strong criteria to play the role of source rock.
The main objectives of this study are to characterize and evaluate the source rock characteristics of the Narimba Formation in the study area. The Narimba Formation is assessed for its oil generation potential by means of organic geochemical analyses which include the determination of the total organic carbon (TOC) content, rock-eval pyrolysis, maceral composition and vitrinite reflectance measurements and geochemical biomarkers. This research is also to provide clues for the stage of the paleodepositional environments and thermal maturity to assess the hydrocarbon generation potential of the source rock in the Narimba Formation. 


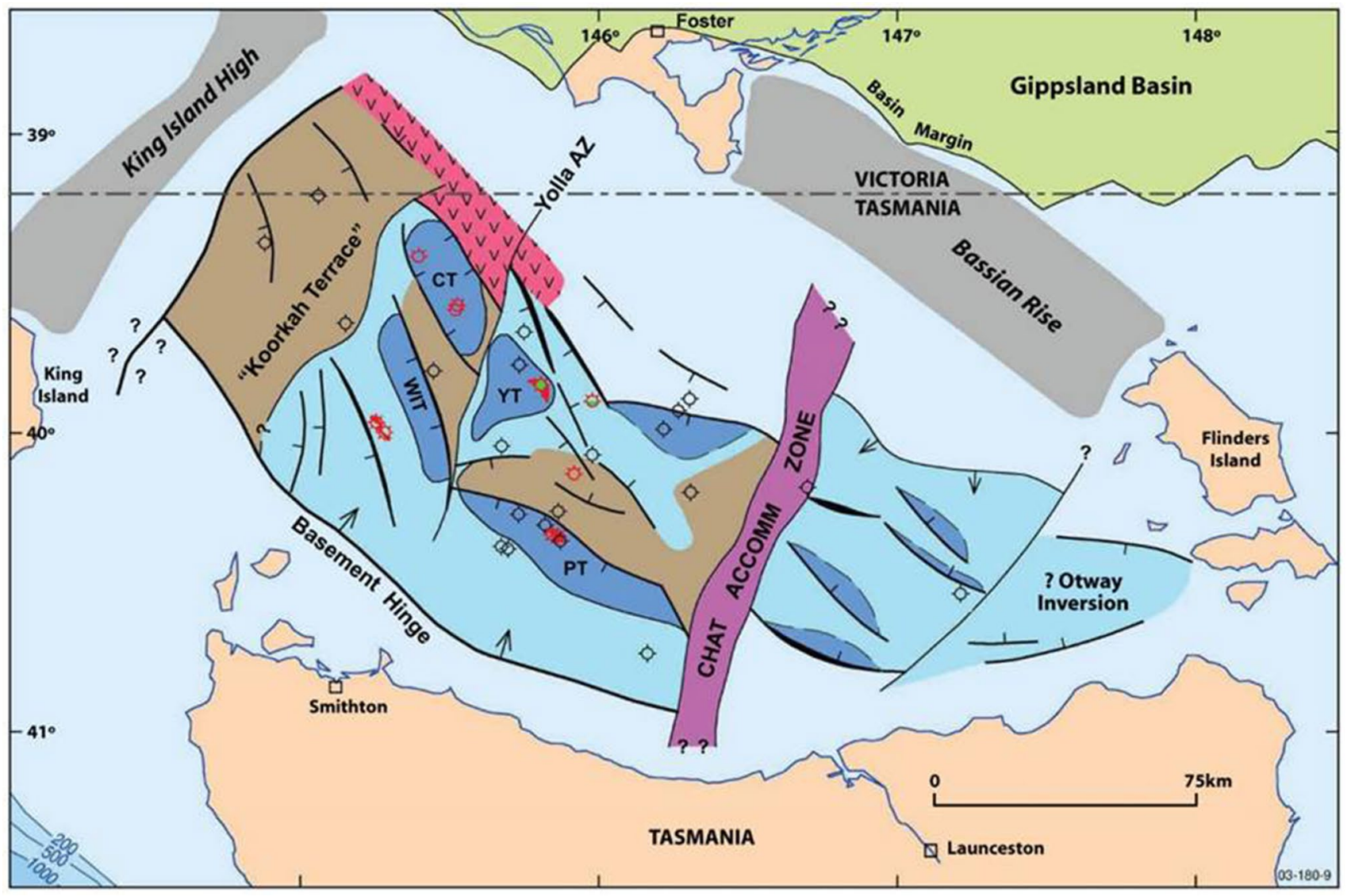

Fig. 2 Regional map showing the location of tectonic elements and generalized basement fault trends in the Bass Basin (Blevin et al. 2003). Cormorant (CT), Yolla (YT), White Ibis (WIT), Pelican troughs (PT) and the Chat Accommodation Zone (CAZ)

\section{Geological background}

\section{Structural setting}

The Bass Basin has been described as a system of multiple northwest-trending, inter-linked half graben dipping northeast and southwest (Etheridge et al. 1985a, b; Lennon et al. 1999; Boreham et al. 2003; Arian 2010). The basin is part of the much larger Southern Rift System, which was initiated during lithospheric extension in the Late Jurassic -Early Cretaceous (Etheridge et al. 1985a, b; Boreham et al. 2003). The Bass Basin underlies the Bass Strait region between Tasmania and Victoria (Fig. 2) in offshore southern Australia (Boreham et al. 2003). It is detached from the Otway Basin by the King Island High to the west and northwest. Bass Basin is also separated from the Gippsland Basin to the northeast by Flinders Island and the Bassian Rise (Fig. 2) (Boreham et al. 2003).

The Bass Basin underwent three phases of extension, based on previous seismic mapping and well log interpretation studies by Etheridge et al. (1985a, b), Lennon et al. (1999), Blevin et al. (2003), Cummings et al. (2004) and
Arian 2010). Later, the basin underwent several periods of compression and reactivation. In the Middle Eocene, minor contractional events took place (Blevin et al. 2003). This is followed by reactivation in the form of right-lateral wrench compression along with the localized extensional structures created by the inversion of Cretaceous-Middle Eocene (Cummings et al. 2004). The fact that the Bass Basin is underlain by basement of differing fabric has also influenced the different structural styles observed within the overlying Mesozoic rift basin (Blevin et al. 2003). The integration of basement geology and mapping of the depocenters has helped to clarify the nature of structural elements within the basin (Blevin et al. 2003).

The Bass Basin is separated into two sub-basins; the Cape Wickham Sub-basin to the west and the Durroon Sub-basin to the east (Fig. 2) (Baillie and Pickering 1991; Boreham et al. 2003; Arian 2010). The Chat Accommodation Zone (CAZ) (Fig. 2) marks the boundary between the Cape Wickham and Durroon sub-basins (Baillie and Pickering 1991). The location of the main Cretaceous half graben in the Cape Wickham Sub-basin (Fig. 2) is shown by the Cormorant (CT), Yolla (YT), White Ibis (WIT) and Pelican troughs 


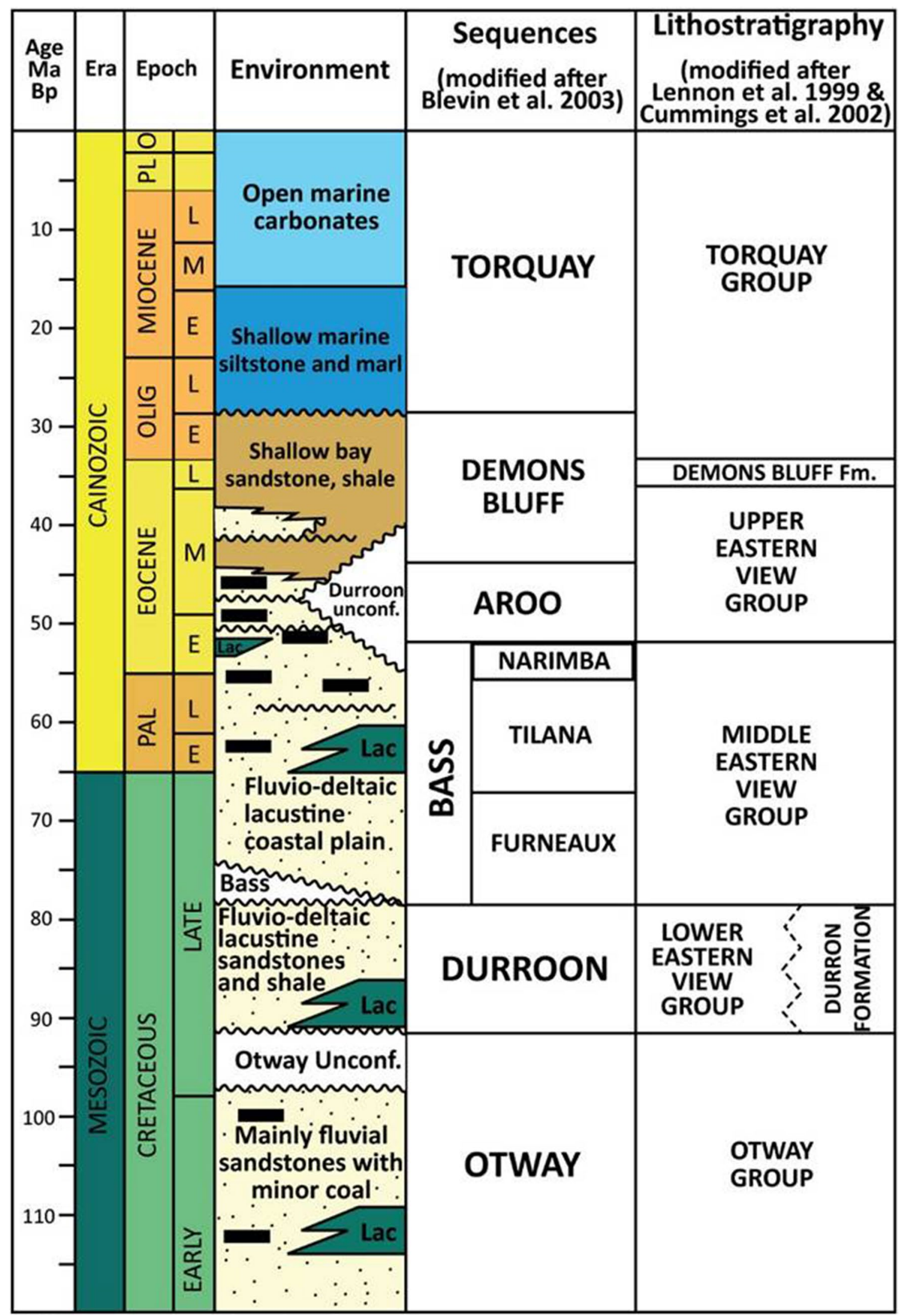

Fig. 3 Lithostratigraphic column of Bass Basin, highlighting the Late Paleocene-Early Eocene Narimba Formation (modified after Cummings et al. 2004) 
(PT) (Blevin et al. 2003). These two depocenters differ in age and structure due to distinct tectonic influences. The easternmost Durroon Sub-basin (Baillie and Pickering 1991) is separated from the western depocenters by a northeasttrending structural accommodation zone (Fig. 2). The extension in the Durroon Sub-basin ceased by Santonian-Campanian time, while tectonic activity in the Otway-Sorell region continued to influence and enhance accommodation in the western Cape Wickham depocenters until the Early-Middle Eocene (Boreham et al. 2003). The Durroon Sub-Basin is affected by extension which is terminated between the Santonian and Campanian, while accommodation zones kept developing in the Cape Wickham Sub-basin (Boreham et al. 2003).

\section{Stratigraphy}

The simplified stratigraphic columnar section of Bass Basin is illustrated in Fig. 3. The most significant coal-bearing section extends from Late Cretaceous to Eocene, encompassing the Eastern View Group and the Demons Bluff Formation (Fig. 3) (Partridge 2002; Arian 2010). Coal deposition had been associated with the availability of deep lakes distributed in the central and northwestern Bass Basin (Partridge 2002). Fluvio-deltaic and lacustrine shales are also potential source rocks, whereas reservoir rock types are generally silty, fluvial channel and delta sands with very little marine influence (Arian 2010). Meandering fluvial channel belts and distributary channels had been identified as the most potential reservoirs (Arian 2010). In addition to the requirement of medium to coarse-grained sands, resistance to compaction (to preserve intergranular porosity) and presence of fractures and secondary porosity also play roles in making a good reservoir. The Middle Eastern View Group (Fig. 3) had been found to bear thick sand zones with excellent lateral continuity (Arian 2010).

The Demons Bluff Formation, which is a regional sealing facies, overlies the Eastern View Group (Fig. 3), and it is made up of fine-grained sediments. This formation also exhibits good lateral extent as well as thickness (100-395 m) (Blevin et al. 2003). Therefore, the reservoirs in the Middle Eastern View Group could potentially be sealed by finingupward cycles within the unit (Arian 2010). The Lower Eastern View Group is made up of the Durroon Megasequence (Fig. 3). It was deposited as a result of the Tasman Rifting, which was the second rift phase underwent by the basin from the Cenomanian to Campanian (Late Cretaceous) (Cummings et al. 2004; Arian 2010). The basaltic basement is overlain by lithologic variation consisting of shale, siltstone and sandstone (Blevin et al. 2005) (Fig. 3).

The Middle Eastern View Group is comprised of the Bass Megasequence which was deposited during the third rift phase (Late Cretaceous-Cenozoic) (Arian 2010). This megasequence is further divided into three formations (Fig. 3), namely the Furneaux, Tilana and Narimba Formations (Blevin et al. 2005). The Furneaux Formation is well imaged on seismic data in the central and western basin, around the Poonboon-1, Tilana-1 and Tarook-1, and Koorkah-1 and Toolka-1A wells (Blevin et al. 2003). Seismic interpretation suggests that the Furneaux Formation was deposited as a syn-rift succession as a result of reactivation of older Early Cretaceous extensional faults (Blevin et al. 2003). Furneaux Formation (Fig. 3) ranges from interbedded fluvio-deltaic sandstones and freshwater lacustrine shales to fluvio-deltaic sandstones and thin interbedded overbank or delta plain shales and coals. The upper sequence boundary is marked by an angular unconformity (Blevin et al. 2005).

Blevin et al. 2003 concluded that the Tilana Formation (Fig. 3) encompasses the latest Maastrichtian to latest Paleocene succession. Seismic correlations suggest that deposition of the Tilana was controlled by a combination of reactivation of underlying Early Cretaceous faults, tectonic subsidence, sediment loading and compaction (Blevin et al. 2003). Some areas of the basin appear to have been unaffected by increased subsidence during this time (Poonboon-1), suggesting that rates of accommodation varied significantly between the different rift segments. This variation in accommodation is clearly shown in the thickness and range of facies types deposited (Blevin et al. 2003).

The latest Late Paleocene to late Early Eocene Narimba Formation (Fig. 3) is the youngest sequence within the Bass Megasequence (Blevin et al. 2003). The Narimba Formation was deposited across most of the Bass Basin as a result of the reactivation of select Early Cretaceous rift faults (Blevin et al. 2003). The Narimba Formation, which is the main focus of this study (Fig. 3), also has a complex composition of sandstones, thin shale beds and coals which are of lacustrine lower delta plain and peat mire origin (Blevin et al. 2005). A combination of high rates of accommodation and a steady supply of sandy sediment feeding down the flanks of the rift from northern Tasmania accounts for the

Table 1 Tops, bottoms and thicknesses of the Narimba Formation as encountered by studied wells, i.e., Pelican-1, Pelican-2, Pelican-3, Pelican-4, Pelican-5, Narimba-1 and Tilana-1

\begin{tabular}{|c|c|c|c|}
\hline Well name & Top depth (m) & $\begin{array}{l}\text { Bottom depth } \\
\text { (m) }\end{array}$ & Thick (m) \\
\hline Plican-1 & 2499 & 3168 & 669 \\
\hline Plican-2 & 2661 & 3068 & 407 \\
\hline Plican-3 & 2661 & 3068 & 407 \\
\hline Plican-4 & 2528 & 3050 & 522 \\
\hline Plican-5 & 2560 & 3110 & 550 \\
\hline Narimba-1 & 2580 & 3354 & 774 \\
\hline Tilana-1 & 2490 & 2990 & 500 \\
\hline
\end{tabular}


Table 2 Rock-eval pyrolysis results for the Narimba Formation in wells Pelican-1 to 5 and Narimba-1

\begin{tabular}{|c|c|c|c|c|c|c|c|c|c|c|c|}
\hline Well name & $\operatorname{Depth}(\mathrm{m})$ & Lithology & $S 1$ & $S 2$ & $S 3$ & TOC & OI & $\mathrm{HI}$ & PI & PY & $T \max$ \\
\hline Pelican-1 & 2825 & Non-coal & 0.61 & 3.62 & 2.02 & 2.24 & 90 & 161 & 0.14 & 4.23 & 435 \\
\hline \multirow[t]{2}{*}{ Pelican-2 } & 2878 & Coal & 18 & 255 & - & 76.35 & - & -334 & 0.07 & 273.00 & 446 \\
\hline & 2912 & Coal & 20.1 & 223 & - & 61.43 & - & -363 & 0.08 & 243.10 & 448 \\
\hline Pelican-3 & 2861 & Non-coal & 0.46 & 2.42 & 4.12 & 2.86 & 144 & 84 & 0.16 & 2.88 & 434 \\
\hline Pelican-4 & 2816 & Non-coal & 0.51 & 16 & - & 10.06 & - & -159 & 0.03 & 16.51 & 442 \\
\hline \multirow[t]{26}{*}{ Pelican-5 } & 2557 & Non-coal & 0.77 & 7.45 & 1.57 & 2.85 & 55 & 261 & 0.09 & 8.22 & 428 \\
\hline & 2565 & Non-coal & 1.86 & 9.19 & 0.72 & 3.02 & 23 & 304 & 0.17 & 11.05 & 424 \\
\hline & 2583 & Non-coal & 5.14 & 25.5 & 0.63 & 8.45 & 7 & 301 & 0.17 & 30.64 & 432 \\
\hline & 2619 & Non-coal & 1.32 & 9.25 & 0.75 & 2.84 & 26 & 325 & 0.12 & 10.57 & 425 \\
\hline & 2637 & Non-coal & 0.92 & 12.4 & 0.33 & 11.10 & 2 & 111 & 0.07 & 13.32 & 434 \\
\hline & 2655 & Non-coal & 0.82 & 5.37 & 1.18 & 2.52 & 46 & 213 & 0.13 & 6.19 & 426 \\
\hline & 2709 & Non-coal & 1.02 & 11.49 & 0.49 & 3.46 & 14 & 332 & 0.08 & 12.51 & 434 \\
\hline & 2727 & Non-coal & 1.27 & 11.01 & 0.74 & 3.68 & 20 & 299 & 0.1 & 12.28 & 433 \\
\hline & 2745 & Non-coal & 0.7 & 5.37 & 0.82 & 2.46 & 33 & 218 & 0.12 & 6.07 & 431 \\
\hline & 2763 & Non-coal & 1.52 & 14.24 & 0.71 & 4.50 & 16 & 316 & 0.1 & 15.76 & 434 \\
\hline & 2790 & Coal & 3.2 & 18.76 & 0.38 & 39.40 & 1 & 48 & 0.15 & 21.96 & 435 \\
\hline & 2794 & Coal & 27.01 & 338.76 & 4.43 & 79.20 & 6 & 428 & 0.07 & 365.77 & 441 \\
\hline & 2808 & Non-coal & 0.75 & 3.89 & 0.94 & 2.04 & 50 & 191 & 0.16 & 4.64 & 435 \\
\hline & 2844 & Non-coal & 2.3 & 13.09 & 0.89 & 3.64 & 24 & 360 & 0.15 & 15.39 & 431 \\
\hline & 2862 & Coal & 2.47 & 15.22 & 0.71 & 18.60 & 4 & 82 & 0.14 & 17.69 & 428 \\
\hline & 2898 & Non-coal & 0.69 & 4.01 & 0.94 & 1.76 & 53 & 228 & 0.15 & 4.70 & 433 \\
\hline & 2916 & Non-coal & 1.21 & 16.08 & 0.85 & 4.20 & 20 & 383 & 0.07 & 17.29 & 433 \\
\hline & 2937 & Non-coal & 0.82 & 2.52 & 1.61 & 1.10 & 146 & 229 & 0.25 & 3.34 & 436 \\
\hline & 2970 & Coal & 1.84 & 14.76 & 0.3 & 17.80 & 2 & 83 & 0.11 & 16.60 & 440 \\
\hline & 2970 & Coal & 23.37 & 235.34 & 4.06 & 72.40 & 6 & 325 & 0.09 & 258.71 & 442 \\
\hline & 2978 & Non-coal & 1.06 & 3.85 & 1.17 & 1.56 & 75 & 247 & 0.22 & 4.91 & 440 \\
\hline & 2988 & Coal & 0.62 & 6.7 & 0.22 & 20.60 & 1 & 33 & 0.08 & 7.32 & 437 \\
\hline & 2991 & Non-coal & 0.72 & 3.86 & 2.23 & 2.00 & 111 & 193 & 0.16 & 4.58 & 442 \\
\hline & 3006 & Non-coal & 1.63 & 9.66 & 1.04 & 6.25 & 17 & 155 & 0.14 & 11.29 & 439 \\
\hline & 3042 & Non-coal & 0.52 & 2.38 & 0.94 & 2.00 & 47 & 119 & 0.18 & 2.90 & 441 \\
\hline & 3060 & Non-coal & 1.87 & 9.49 & 0.46 & 4.50 & 2 & 36 & 0.16 & 11.36 & 439 \\
\hline \multirow[t]{4}{*}{ Narimba-1 } & 2759 & Coal & 10.7 & 200 & & 43.96 & & 455 & 0.05 & 210.70 & 438 \\
\hline & 2835 & Coal & 26.5 & 65.7 & & 23.13 & & 284 & 0.29 & 92.20 & 434 \\
\hline & 2878 & Non-coal & 0.18 & 1.6 & & 3.14 & & 51 & 0.1 & 1.80 & 430 \\
\hline & 3198 & Non-coal & 0.75 & 22.22 & & 11.95 & & 186 & 0.03 & 22.90 & 445 \\
\hline
\end{tabular}

unusually high rate of sedimentation in the Pelican Trough (Blevin et al. 2003).

The Upper Eastern View Group contains the Aroo Formation (Fig. 3). It was formed during thermal subsidence at a rift transition period, likely to be the transition between the second and third rift phases (Boreham et al. 2003). The Aroo Formation is considered as intercalations of sandstones, siltstones, carbonaceous shales and coal seams (Meszoly et al. 1985). Due to a decrease in rate of deposition, the coal successions have higher frequencies and thicknesses (Blevin et al. 2005; Arian 2010).

\section{Data and methodology}

Geochemical dataset is retrieved from the Government of Western Australia, Department of Mines, Industry Regulation and Safety. Source rock characterization has been performed using geochemical analyses data applied on different samples collected from different wells. The geochemical datasets utilized in this source rock evaluation include total organic carbon (TOC) content, rock-eval pyrolysis, vitrinite reflectance, maceral composition and the biomarkers (Tables 2, 3, 4, 5). These methods gave insights on the quantity, quality and thermal maturity of the source rocks. Biomarker data facilitate the definition of the thermal maturity, hydrocarbon potentiality and paleodepositional 
Table 3 Vitrinite reflectance data for the Narimba Formation within the wells Pelican-1 to 5, Narimba-1 and Tilana-1

\begin{tabular}{|c|c|c|}
\hline Well name & Depth (m) & Mean $\% R o$ \\
\hline \multirow[t]{3}{*}{ Pelican-1 } & 2497 & 0.69 \\
\hline & 3060 & 0.86 \\
\hline & 3062 & 0.81 \\
\hline \multirow[t]{4}{*}{ Pelican-2 } & 2875 & 0.8 \\
\hline & 2882 & 0.81 \\
\hline & 2913 & 0.82 \\
\hline & 2915 & 0.81 \\
\hline \multirow[t]{2}{*}{ Pelican-3 } & 2802 & 0.67 \\
\hline & 2810 & 0.71 \\
\hline \multirow[t]{2}{*}{ Pelican-4 } & 2815 & 0.75 \\
\hline & 2815 & 0.73 \\
\hline \multirow[t]{6}{*}{ Pelican-5 } & 2646 & 0.77 \\
\hline & 2691 & 0.7 \\
\hline & 2691 & 0.73 \\
\hline & 2838 & 0.69 \\
\hline & 2862 & 0.82 \\
\hline & 3024 & 0.88 \\
\hline \multirow[t]{7}{*}{ Narimba-1 } & 2747 & 0.67 \\
\hline & 2825 & 0.62 \\
\hline & 2885 & 0.56 \\
\hline & 3051 & 0.71 \\
\hline & 3176 & 0.78 \\
\hline & 3196 & 0.79 \\
\hline & 3204 & 0.78 \\
\hline \multirow[t]{5}{*}{ Tilana-1 } & 2687 & 0.62 \\
\hline & 2697 & 0.62 \\
\hline & 2805 & 0.6 \\
\hline & 2895 & 0.83 \\
\hline & 2978 & 0.75 \\
\hline
\end{tabular}

environment of the formation of interest. The subsequent classifications of quality, quantity and thermal maturity were done in accordance with Tissot and Welte (1978), Peters (1986), Peters and Cassa (1994).

Rock eval and total organic carbon (TOC) were determined using a Rock Eval 6 instrument. Vitrinite reflectance and fluorescence measurements were taken using the procedures described in Newman (1997) and Newman et al. (2000). Gas chromatography-mass spectrometry of the saturated hydrocarbons using selected ion monitoring (GCMSSIR) and compound-specific carbon isotopic analysis of the $\mathrm{n}$-alkanes by gas chromatography-combustion-isotope ratio mass spectrometry (GC-C-IRMS) were conducted according to Boreham and Summons (1999).

A total of $\mathbf{3 5}$ source rock samples have been collected from 7 wells, namely Pelican-1, Pelican-2, Pelican-3, Pelican-4, Pelican-5, Narimba- 1 and Tilana- 1 in the Bass Basin (Fig. 1). Top and bottom depths of the Narimba Formation, together with thicknesses as encountered by the studied wells, are presented in Table 1, illustrating values that range from 2490 to $2661 \mathrm{~m}, 2990$ to $3354 \mathrm{~m}$ and 407 to $774 \mathrm{~m}$, respectively.

Rock-eval pyrolysis data have been performed on $\mathbf{3 5}$ samples as follows: Pelican-1 (one sample), Pelican-2 (two samples), Pelican-3 (one sample), Pelican-4 (one sample), Pelican-5 (26 samples), Narimba-1 (4 samples) (Table 2): the volume of volatile hydrocarbon (bitumen) already available in the source rock $(S 1)$; volume of hydrocarbon generated during pyrolysis (S2); amount of carbon dioxide emitted (S3); maximum pyrolysis temperature ( $T \max )$; and measurement of the total organic carbon (TOC). Hydrogen index (HI) and oxygen index (OI) and some other parameters have been calculated by using rock-eval parameters (Espitalié et al. 1977; Peters 1986).

Vitrinite reflectance is the measurement of the degree with which light will be reflected for vitrinite polished surface which varies according to the level of thermal maturity (Mukhopadhyay and Hatcher 1993; Law 1999; Wilkins and George 2002). Vitrinite reflectance data for 29 samples collected from the wells Pelican-1, 2, 3, 4, 5, Narimba-1 and
Table 4 Biomarker data and parameters calculated from n-alkanes and isoprenoids for Pelican-1, Pelican-3, Pelican-5 and Tilana-1

\begin{tabular}{lllllllll}
\hline Well name & Depth $(\mathrm{m})$ & $\mathrm{Pr} / \mathrm{Ph}$ & $\mathrm{Pr} / \mathrm{nC} 17$ & $\mathrm{Ph} / \mathrm{nC18}$ & $\mathrm{CPI}$ & $\mathrm{nC27}$ & $\mathrm{nC28}$ & $\mathrm{nC29}$ \\
\hline Pelican-1 & 2825 & 8.36 & 5.17 & 0.87 & 1.13 & 5.8 & 5.3 & 6.6 \\
Pelican-3 & 2861 & 7.02 & 4.76 & 0.85 & 1.2 & 5.7 & 4.7 & 5.2 \\
Pelican-5 & 2788 & - & - & - & - & 29 & 19 & 52 \\
& 2790 & 4.7 & 0.84 & 0.15 & - & 12 & 44 & 44 \\
& 2961 & 4.9 & 0.87 & 0.17 & - & & & \\
& 2169 & 9.8 & 4.8 & 0.6 & - & & & \\
& 2691 & 5.5 & 0.86 & 0.12 & - & & & \\
Tilana-1 & 2691 & 7.5 & 2.5 & 0.25 & - & & & \\
\hline & 2800.9 & 8.44 & 7.28 & 1.00 & 1.22 & 8.5 & 6.6 & \\
& & & & & & & & \\
\end{tabular}


Table 5 Biomarker parameters calculated from steranes, hopanes and terpanes

\begin{tabular}{llccllll}
\hline Well name & Depth $(\mathrm{m})$ & $\mathrm{nC} 19$ & $\mathrm{nC} 23$ & $\mathrm{C} 29 /(\mathrm{C} 29+\mathrm{C} 27)$ & $\mathrm{C} 19 /(\mathrm{C} 19+\mathrm{C} 23)$ & $\mathrm{C} 27 / \mathrm{C} 29$ & $\mathrm{C} 27 /(\mathrm{C} 27+\mathrm{C} 29)$ \\
\hline Pelican-1 & 2825 & 2.4 & 3.1 & 0.532 & 0.436 & 0.879 & 0.468 \\
Plican-3 & 2861 & 2.3 & 3.3 & 0.477 & 0.411 & 1.096 & 0.523 \\
Plican-5 & 2788 & - & - & 0.642 & - & 0.558 & 0.358 \\
& 2790 & - & - & 0.786 & - & 0.273 & 0.214 \\
Tilana-1 & 2800 & 1.7 & 4.1 & 0.511 & 0.293 & 0.955 & 0.489 \\
\hline
\end{tabular}

Table 6 Maceral composition (vitrinite, inertinite and liptinite) data for the Narimba Formation in Pelican-5 well

\begin{tabular}{llcl}
\hline Depth (m) & Vitrinite (\%) & Inertinite (\%) & Liptinite (\%) \\
\hline Plican-5 well & & & \\
$2592-2601$ & 70 & 5 & 25 \\
$2745-2754$ & 80 & 5 & 15 \\
& 45 & 30 & 25 \\
2790 & 45 & 5 & 50 \\
$2790-2799$ & 65 & 5 & 30 \\
2937 & 55 & 40 & 5 \\
$2961-2970$ & 70 & 10 & 20 \\
\hline
\end{tabular}

Tilana- 1 were utilized in this study as indicators of thermal maturity (Table 3). The maceral composition for $\mathbf{7}$ samples from Plican-5 well has been provided by the Government of Western Australia, Department of Mines, Industry Regulation and Safety (Table 6).

The biomarker data (9 samples) from the wells Pelican-1 (one sample), Pelican-3 (one sample), Pelican-5 (6 samples) and Tilana-1 (one sample) have been used to identify paleodepositional environment of the Narimba Formation source rocks (Tables 4, 5).
Biomarkers are 'molecular fossils' which retain most of the original carbon skeleton of their original form (Philp and Lewis 1987; Simoneit 2002).

Biomarkers are a group of degradation-resistant compounds which are primarily hydrocarbons and can be found in oil, rocks, sediments and soil extracts (Philp and Lewis 1987; Simoneit 2002). These 'molecular fossils' are distinguishable from other compounds as they retain most of the original carbon structure of the original material, such as previous living organisms (Mobarakabad et al. 2011). They are present predominantly and globally and, hence, are very useful in indicating organic source material, paleodepositional environment, thermal maturity and source rock quality (Moustafa and Morsi 2012).

The interpretations of the biomarker data and its derivatives such as the pristane/phytane ratio, isoprenoid/nalkanes ratio, hopanes, terpanes, concentration of regular steranes $\left(\mathrm{C}_{27}, \mathrm{C}_{28}\right.$ and $\left.\mathrm{C}_{29}\right)$ and carbon preference index (CPI) have been performed following the research done by Philp and Lewis (1987), Peters and Moldowan (1993), Peters and Cassa (1994), Simoneit, (2002), Peters et al. (2005), Rodriguez and Philp (2015), Ayinla et al. (2017), Jumat et al. 2018, Osli et al. 2018, 2019 and Shalaby et al. $2019 b)$. The organic petrographical data used are the maceral analysis and vitrinite reflectance measurements on samples collected from Pelican-5 Well. The volumetric
Fig. 4 A cross-plot of $S 1$ versus TOC indicating the origin of the hydrocarbon within the Narimba Formation (Fakhri et al. 2013)

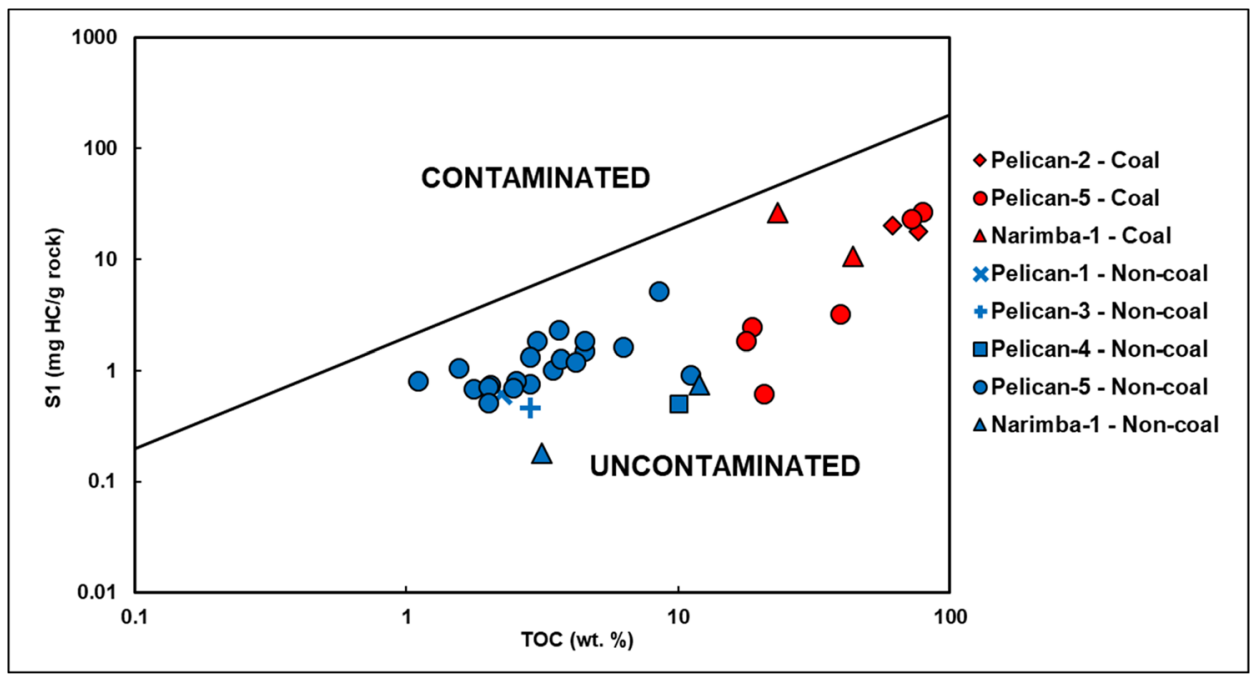


Fig. 5 PY versus TOC crossplot indicating hydrocarbon generating potential

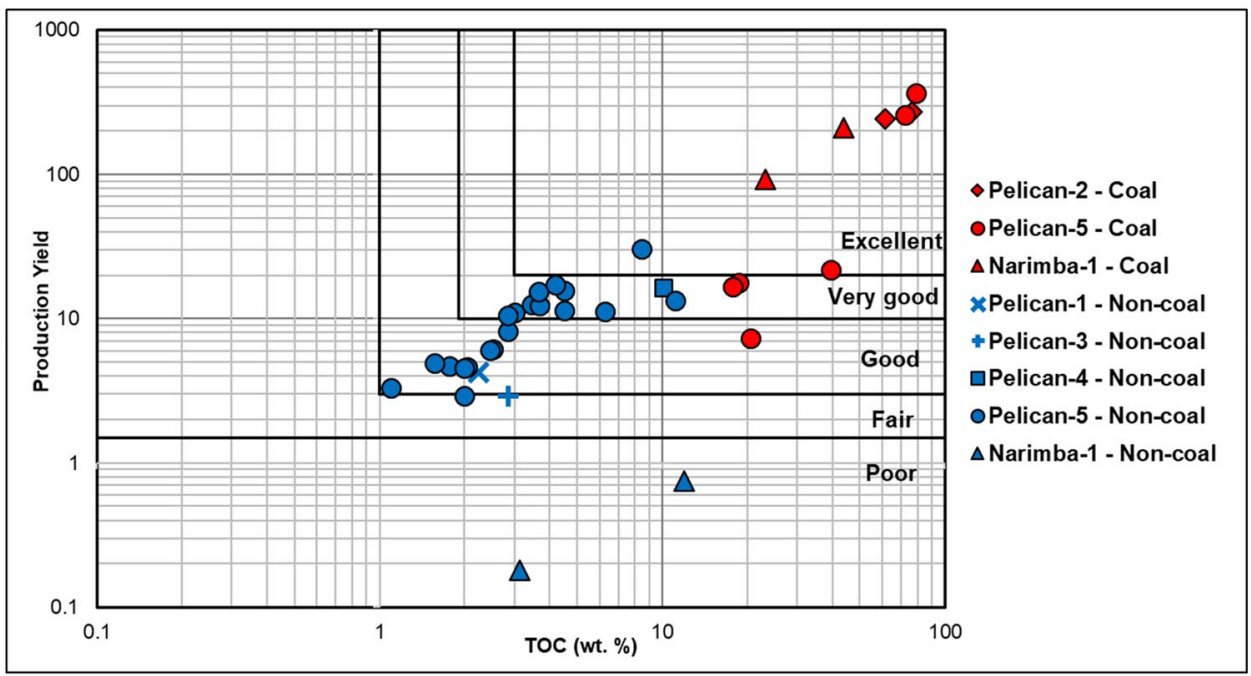

maceral composition of the proportions of vitrinite, liptinite and inertinite has been provided by Government of Western Australia, Department of Mines, Industry Regulation and Safety.

\section{Results and discussion}

\section{The geochemical analyses and organic richness}

The geochemical analyses for the total of 35 samples from the studied wells have been interpreted. Table 2 shows these rock-eval pyrolysis results and other associated parameters in detail. Out of the total number of samples, $28.6 \%$ was coal and the remaining $71.4 \%$ have been interpreted as noncoal (shale and mudstones). The free volatile hydrocarbon, $S 1$ values, ranged from 0.18 to $27.01 \mathrm{mgHC} / \mathrm{gm}$ rock. The pyrolyzed hydrocarbon, $S 2$ values, ranged from 1.60 to $338.76 \mathrm{mgHC} / \mathrm{gm}$ rock, and the total $\mathrm{CO}_{2}, \mathrm{~S} 3$ values ranged from 0.22 to $4.43 \mathrm{mgCO}_{2} / \mathrm{gm}$ rock. The maturity parameter, Tmax, is the maximum temperature at which the peak hydrocarbon generation from cracking the kerogen is recorded to range from 424 to $448^{\circ} \mathrm{C}$. Total organic carbon (TOC) content indicates the quantity of organic richness, and it is found to range from 1.1 to $79.2 \mathrm{wt}$. \%. Subsequently, the source rock potentiality represented by hydrogen index (HI) and oxygen index (OI) values produced ranges of 33 to $455 \mathrm{mg}$ $\mathrm{HC} / \mathrm{g}$ TOC and 1 to $146 \mathrm{mg} \mathrm{CO}_{2} / \mathrm{g} \mathrm{TOC}$, respectively. Additional parameters attained were production yield (PY) values which gave a value range of 1.80 to 365.77 and production index (PI) can also use to reflect the maturity and it ranges from 0.03 to 0.29 .

Vitrinite reflectance (\%Ro) is an optical parameter describing the degree of coalification and, hence, the
Fig. $6 S 2$ versus TOC crossplot for quality and quantity of organic matter (Espitalié et al. 1985)

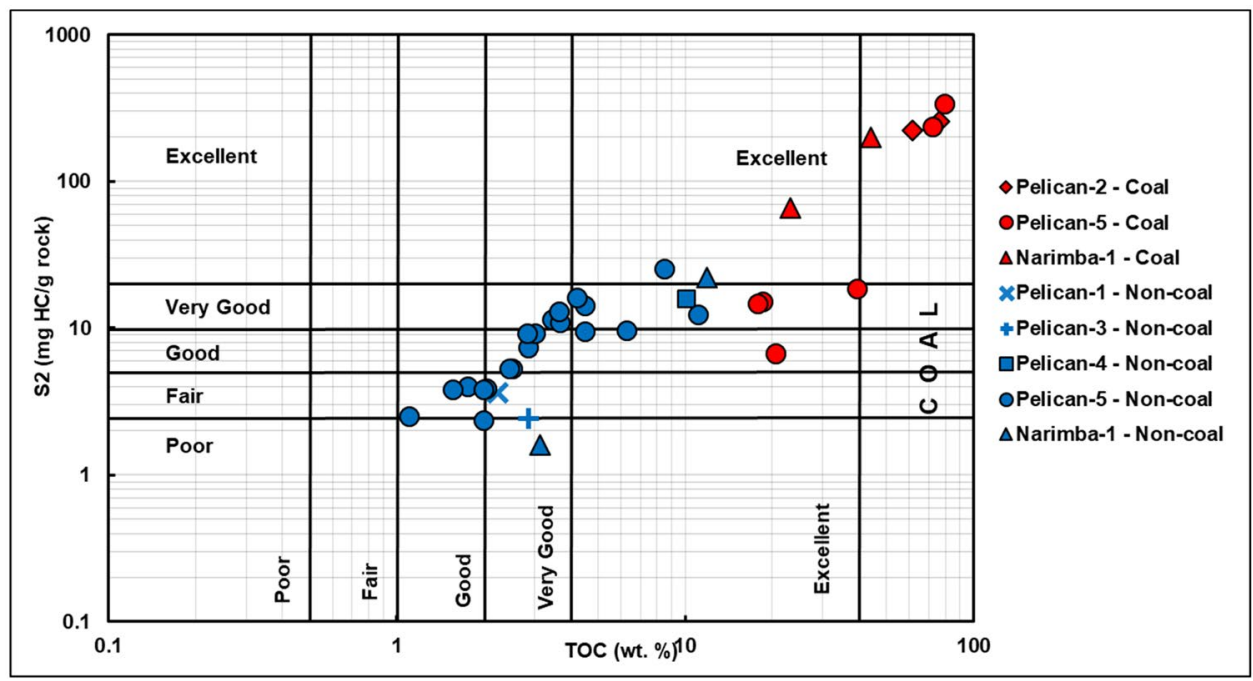


Fig. $7 \quad S 2$ versus TOC cross-plot to identify kerogen typing of organic matter (Langford and Blanc-Valleron 1990)

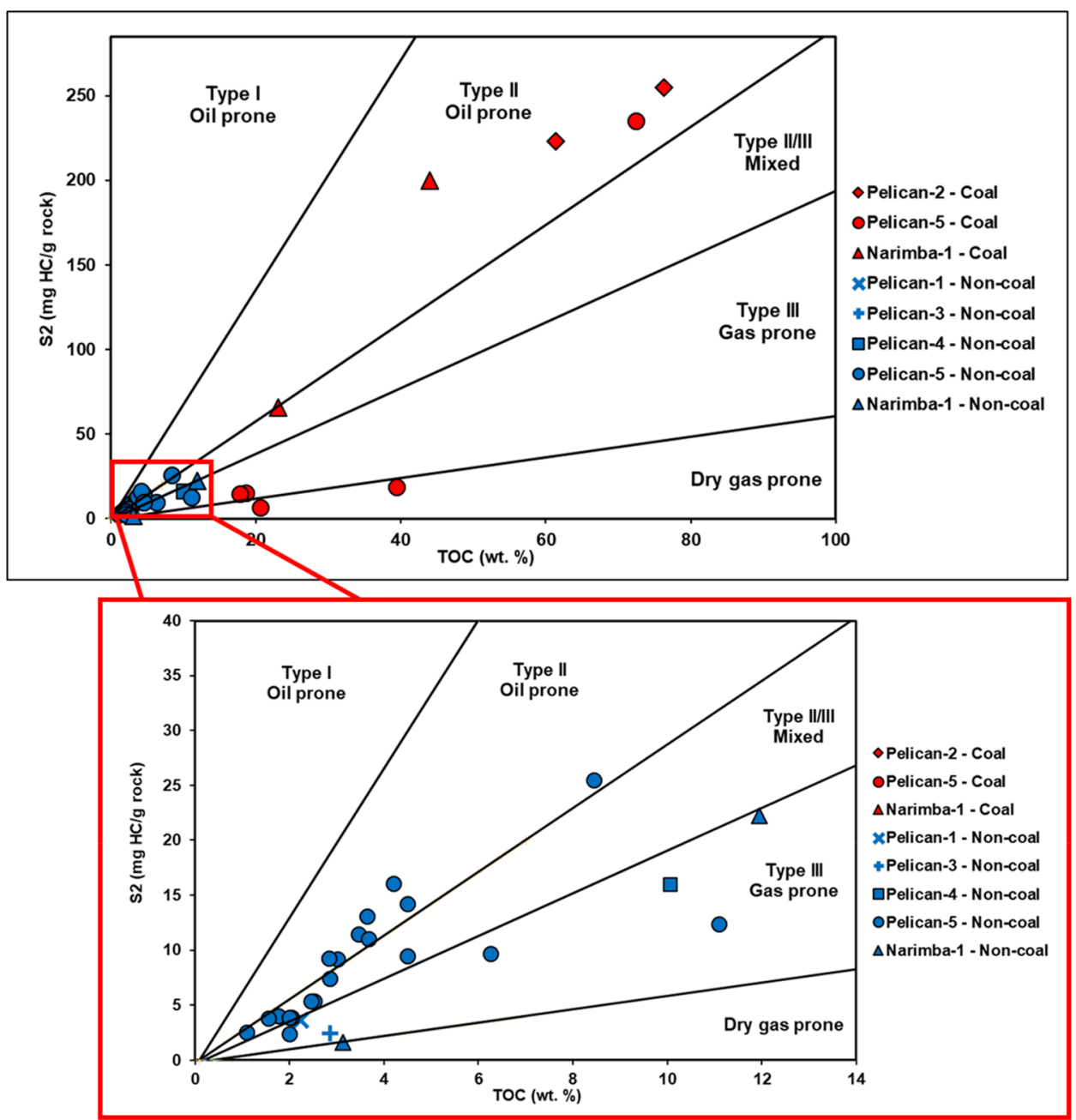

degree of organic matter thermal maturity in source rocks (Mukhopadhyay 1994; Mukhopadhyay and Hatcher 1993; Wilkins and George 2002). As thermal evolution causes alteration in chemical composition of vitrinite, the reflectance values also change. Generally, vitrinite reflectance values of $0.2-0.6 \%$ correspond to immature organic matter, $0.6-1.35 \%$ is mature, and $>1.35 \%$ is postmature (Peters and Cassa 1994). The summary of vitrinite reflectance (Ro\%) data relative to depth for the Narimba Formation within the studied wells shows the minimum and maximum values have been recorded in Plican-5 well as 0.37 and 1.41, respectively (Table 3).

The biomarkers data (CPI, the isoprenoids $(\mathrm{Pr} / \mathrm{Ph})$, isoprenoids/n-alkanes distribution $\left(\mathrm{Pr} / \mathrm{nC}_{17}\right.$ and $\left.\mathrm{Ph} / \mathrm{nC}_{18}\right)$, in addition to the regular sterane biomarkers $\left(\mathrm{C}_{27}, \mathrm{C}_{28}\right.$ and $\mathrm{C}_{29}$ ) utilized in this study are presented in Tables 4,5 . The percentages of vitrinite, liptinite and inertinite available for samples from Pelican-5 are listed in Table 6. The average percentages of vitrinite, inertinite and liptinite compositions were $60.9 \%, 16.6 \%$ and $23.1 \%$, respectively. Maceral composition data can be utilized to further evaluate the type, potentiality and thermal maturity of organic matter within the source rock.

The source rock generated hydrocarbon from the Narimba Formation can be evaluated by the use of the cross-plot relationship of $S 1$ versus TOC shown in Fig. 4, applied according to Fakhri et al. (2013). It indicates that the Narimba source rock hydrocarbon was originally generated within the source rocks themselves and not affected by any contamination or migration from elsewhere.

Pyrolysis results can be utilized to identify the types of organic matter in terms of quantity and quality. Quantity of organic matter refers to the amount of organic matter available in which higher amounts are more favorable to generate hydrocarbon. Organic matter quality refers to whether the organic matter is suitable to produce either oil, gas or both. The TOC measurements shown in Table 2 which show a range from 1.1 to $79.2 \mathrm{wt} \%$ indicate that the Narimba Formation is a promising potential source rock with good to excellent quantity of organic matter, based on the TOC classification introduced by Peters and Cassa (1994). 
Fig. 8 Modified Van Krevelen diagram (HI versus OI) for determining the type of kerogen present in the source rock (Espitalié et al. 1985)

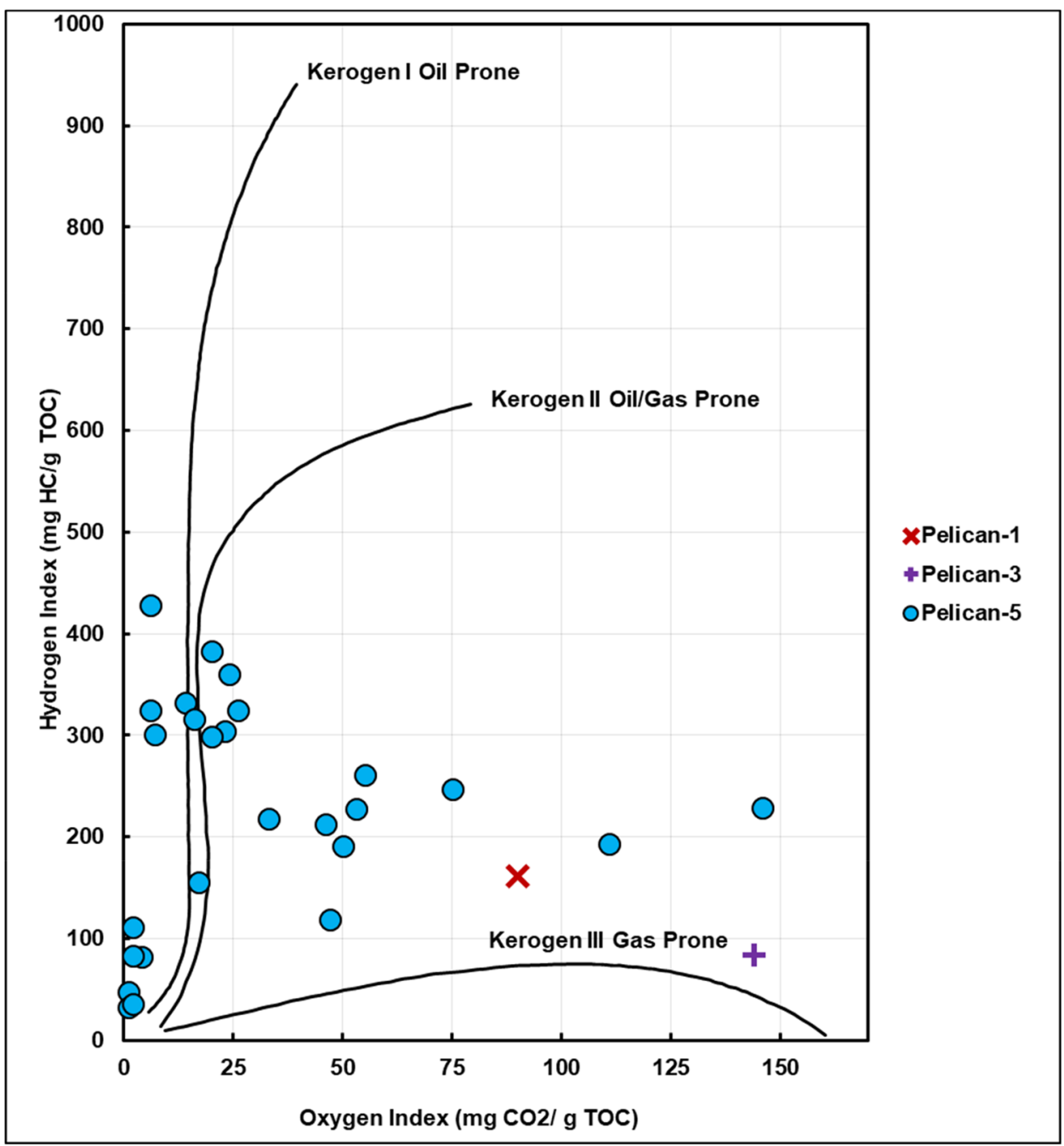

\section{Type of kerogen and source rock potential}

Hydrocarbon generation potential can be demonstrated by cross-plotting production yield (PY) versus TOC as shown in Fig. 5 (Shalaby et al. 2011, 2012a, b, c and Qadri et al. 2016). Production yield (PY), obtained by summing up $S 1$ and $S 2$, aims to measure the total quantity of hydrocarbon that can be generated from the source rock. The plot shows that majority of the studied samples show good to excellent generation potential, while only a few non-coal samples can display poor to fair potential.

Figure 6 shows the relationship of $S 2$ and TOC, which represent quality and quantity, respectively (Espitalié et al. 1985). Results are wide-ranged, encompassing good to excellent organic matter quantity based on TOC and dominantly fair to excellent hydrocarbon quality based on $S 2$. Plotting of $S 2$ vs TOC can also give further indication of the quality or kerogen types in Fig. 7 (Langford and BlancValleron 1990). It illustrates how coal samples can be interpreted as Kerogen Type-II, Type-II/III and Type-III which is oil prone, oil-gas prone and gas prone, respectively. The result shows that samples from Pelican-5 are mostly Type-II (oil) and Type-II/III (mixed). Minorly, Narimba-1 samples are Type-II (oil) and Type-III (gas prone).

The relationship between HI (S2/TOC) and OI (S3/TOC), demonstrated by the modified Van Krevelen diagram in Fig. 8, can also give indication of the quality of organic matter (Tissot and Welte 1978; Espitalié et al. 1985; Waples 1985; Peters and Cassa 1994). According to the plot, the available data show the abundance of kerogen Type-II, Type-II-III and Type-III which are oil, mixed and gas prone, respectively (Peters 1986; Peters and Cassa 1994) which is in good agreement with results from Fig. 7.

Figure 9 demonstrates the correlation of concentrations of macerals composition (vitrinite, liptinite and inertinite) for samples collected from the well Pelican-5 in a ternary diagram. The data are collected from 7 samples covering the interval of the Narimba Formation (2592-2970 m) in Plican-5 well to characterize the quality of organic matter 
Fig. 9 Ternary diagram correlating concentrations of vitrinite. Liptinite and inertinite to identify organic matter quality

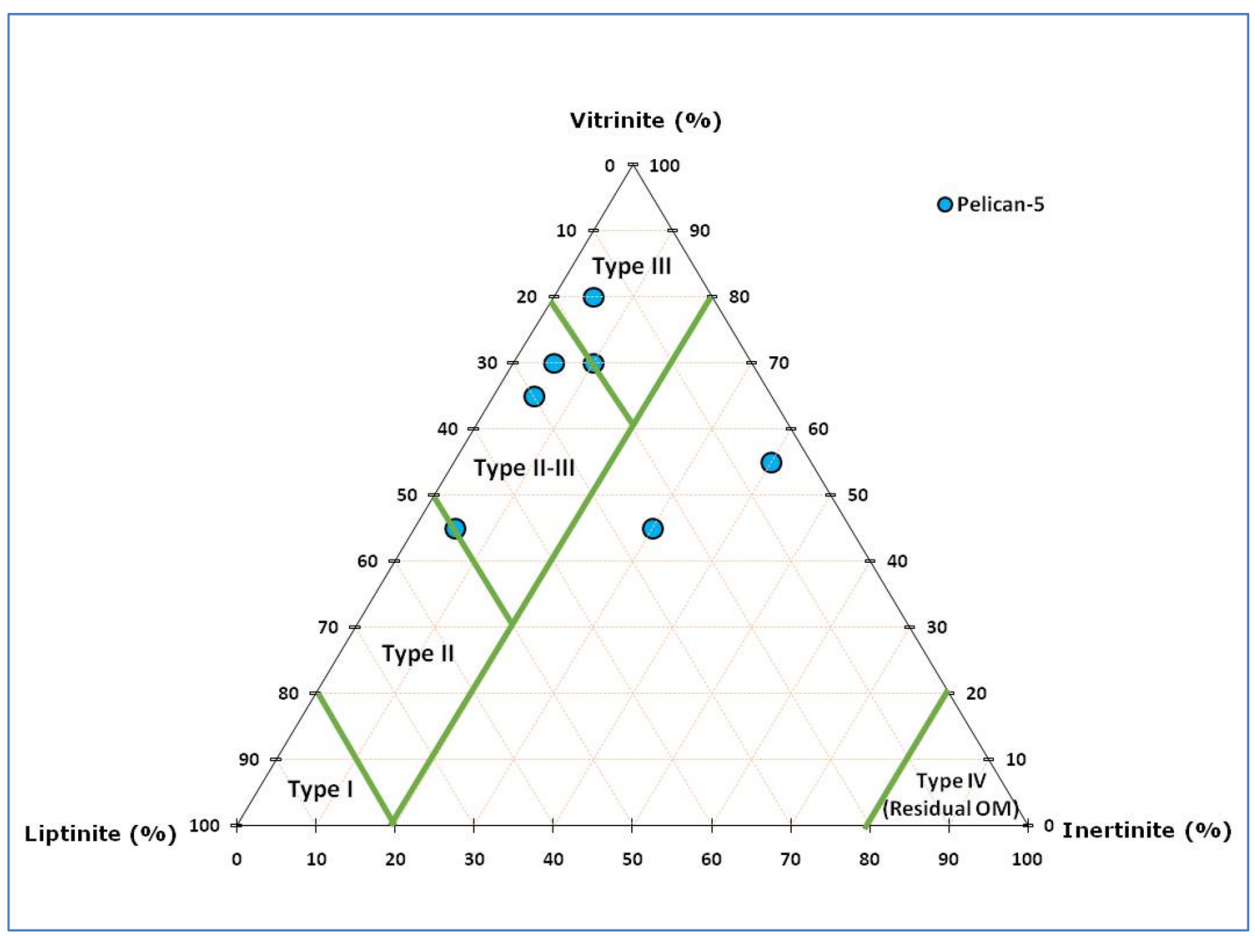

in the Narimba source rocks. The data indicate that samples are of Type-II/III and Type-III, meaning that they are oil-gas prone and gas prone, respectively. This further affirms the results obtained from Figs. 7 and 8.

\section{Thermal maturity}

Thermal maturity is another important factor for source rock evaluation in addition to organic richness and quality. The parameters which can be used to determine thermal maturity are $T \max$, vitrinite reflectance (Ro\%) and production index (PI) (Barker 1974; Peters and Cassa 1994; Shalaby et al. 2011, 2012a, b, c). The maturity parameters (Tmax and Ro\%) were under investigations and evaluation by Shalaby et al. (2019a, 2020). The study explains the prediction of these parameters in case of absence of geochemical analyses. In this study, Tmax is the temperature reached at maximum kerogen generation, i.e., the peak of $S 2$ (Espitalié et al. 1985) and increases proportionally with level of thermal maturity (Barker 1974; Espitalié et al. 1977). According to Peters and Cassa (1994), the Tmax values shown in Table 2, which range from 424 to $448{ }^{\circ} \mathrm{C}$, indicate a wide range of thermal maturity throughout the source rocks in the formation, i.e., immature to peak mature.

To further evaluate the maturity level of organic matter, a cross-plot of HI versus Tmax can be implemented. This is illustrated in Fig. 10 which indicates that samples are majorly Type-II/III and Type-III and are within the mature oil window. These results correspond to the results from Figs. 7 and 8.

$\mathrm{PI}$ was obtained by using the formulae $\mathrm{PI}=S 1 /(S 1+S 2)$. The parameter represents the proportion of free hydrocarbons already generated (bitumen) to the total amount of hydrocarbon that can be generated (bitumen plus kerogen) (Tissot and Welte 1978; Peters and Cassa 1994). Table 2 shows the PI values (ranging from 0.03 to 0.29 ) indicating that the source rocks range from immature to peak mature (Peters 1986; Peters and Cassa 1994). Figure 11 shows a cross-plot between Tmax and production index (PI) showing that samples are mostly immature to mature.

A cross-plot demonstrating the distribution of Tmax and vitrinite reflectance (Ro\%) with increasing depth is shown in Fig. 12 (Shalaby et al. 2012c). The plot reflects that most of samples are located within the mature oil window and show increase in maturity with depth. This provides further confirmation to affirm that source rock samples became more mature and its maturity increases with increasing depth. Hence, the majority of the samples are in agreement with the results of Figs. 9, 10, 11.

With regard to biomarkers, carbon preference index (CPI) can be used as a thermal maturity indicator. Carbon preference index (CPI) of organic matter is defined as the ratio between the sum of odd-numbered carbon alkanes to the sum of even-numbered carbon alkanes. CPI values which are either significantly high or less than 1 relate to thermally immature source rocks (Peters et al. 2005). From this parameter, thermal maturity of the source rock and the source of the organic matter can be defined (Tissot and 
Fig. 10 Cross-plotting HI versus $T$ max to indicate source rock thermal maturity
Fig. $11 T$ max versus PI for further indication of thermal maturity
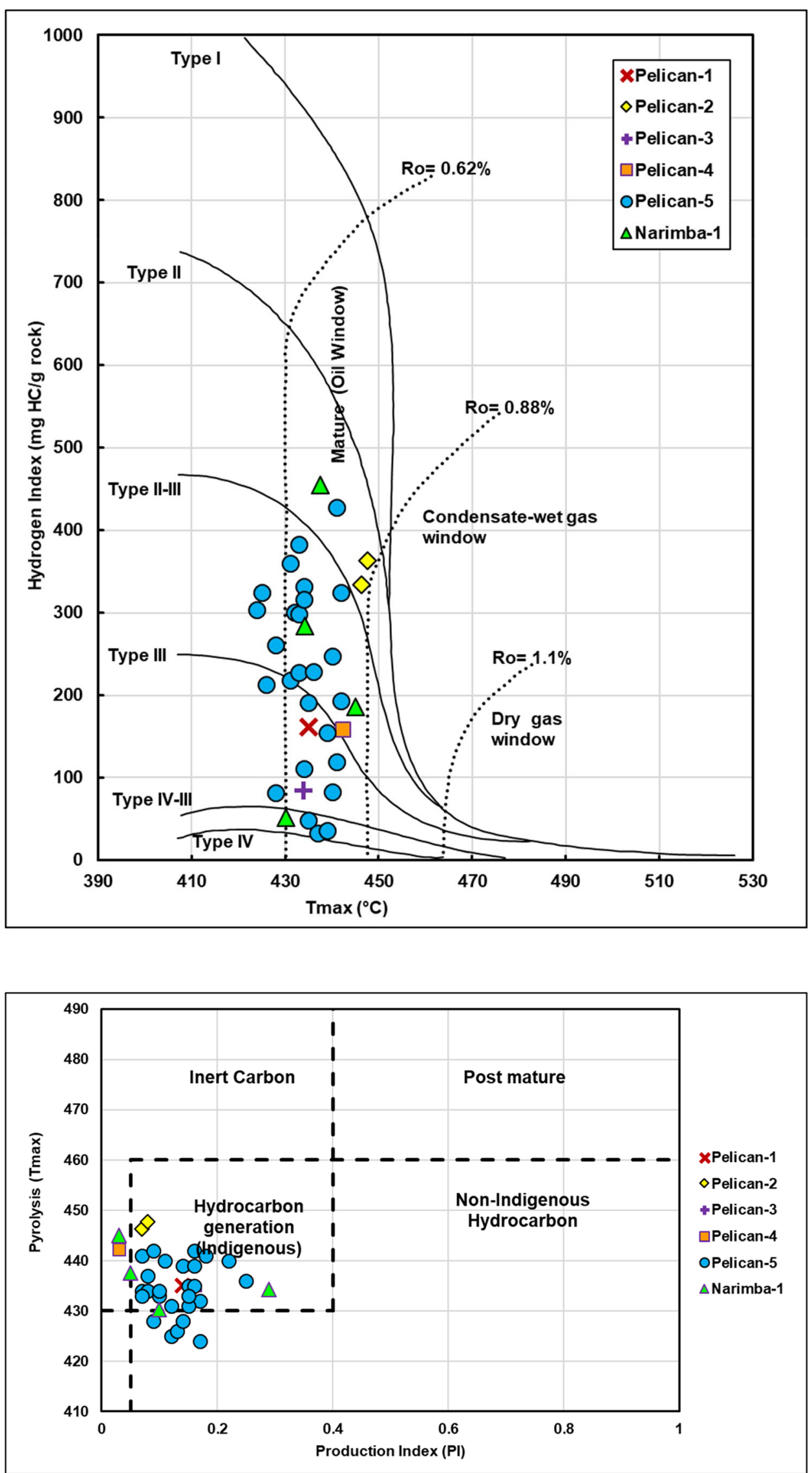

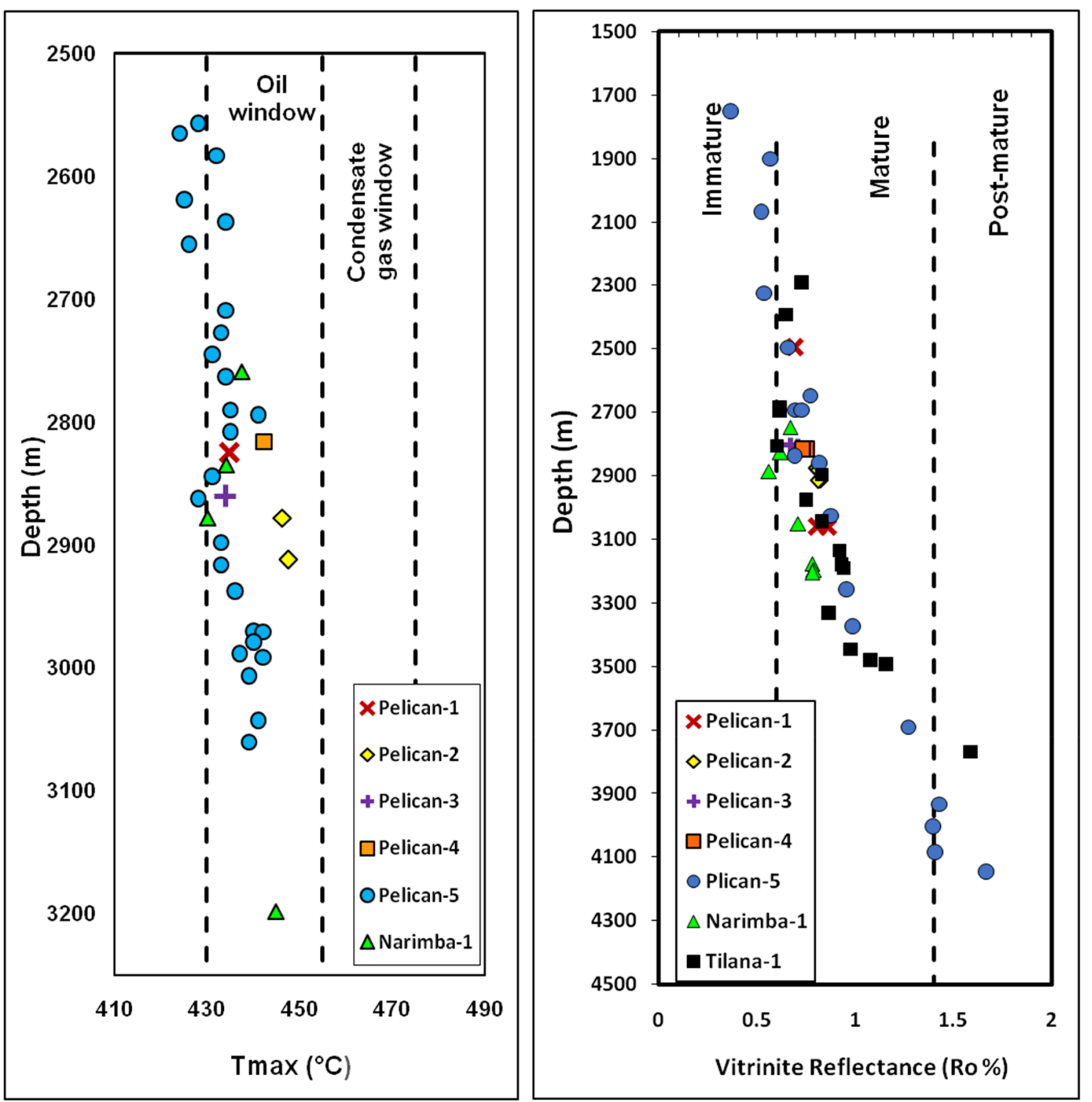

Fig. 12 Tmax and vitrinite reflectance versus depth showing the trend of maturity levels with depth

Welte 1978). CPI values for samples from the wells Pelican-1, Pelican-3 and Tilana-1 in Table 4 range from 1.11 to 1.85 . This indicates that the samples vary from being mature to immature. CPI values are observed to become closer to 1 with increasing depth.

The gas chromatograms (Fig. 13) are also useful for thermal maturity interpretations where a lack of higher molecular weight compounds would mean a higher degree of maturity. This is due to the tendency of longer atom chains to be broken down into shorter chains as a sample matures. In Fig. 13a, b, d, the abundance of higher molecular weight compounds suggests that thermal maturation has not reached the level where longer atom chains are broken down into shorter chains. Thus, we can interpret the maturity level to be early mature (oil window to oil/ gas window). In contrast, Fig. 13c shows there is a lower concentration of higher molecular weight compounds, suggesting a higher level of maturity than observed in Fig. 13a, b, d possibly in the oil/gas window. These observations correlate well with those from Figs. 9, 10, 11, 12.

\section{Paleodepositional environment}

$\mathrm{N}$-alkanes distribution can help to identify the depositional environment of source rock samples. Figure 13 shows the GC results for samples from the Plican-1, 3 and 5 wells. Bimodal $n$-alkane distributions with predominance of both lower and higher molecular weight compounds are clearly 

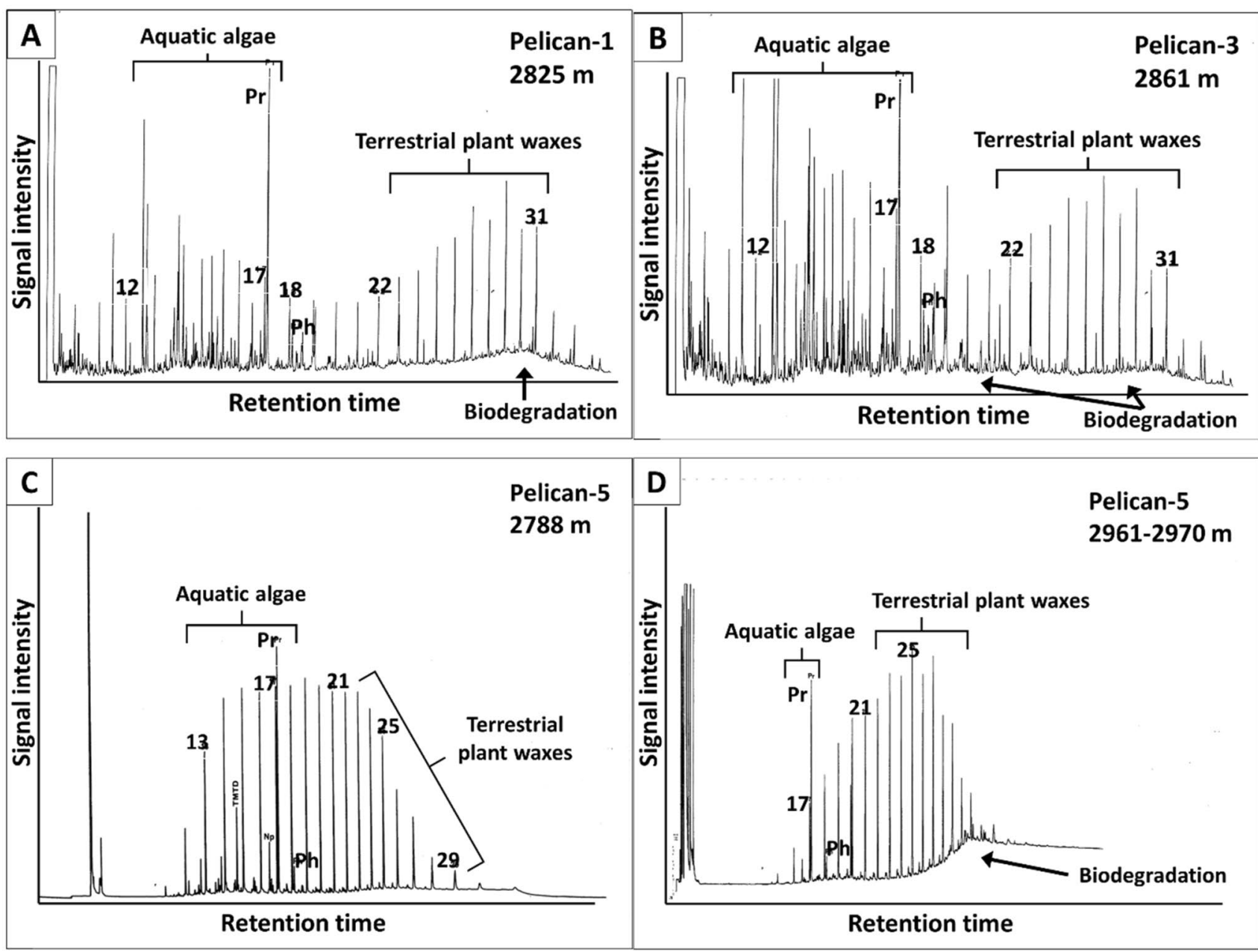

Fig. 13 Gas chromatograms of extracted saturates of samples from the Narimba Formation

Fig. 14 Cross-plot of $\mathrm{Pr} / \mathrm{nC}_{17}$ versus $\mathrm{Ph} / \mathrm{nC}_{18}$ showing depositional environment and maturity level (modified from Peters et al. 2005)

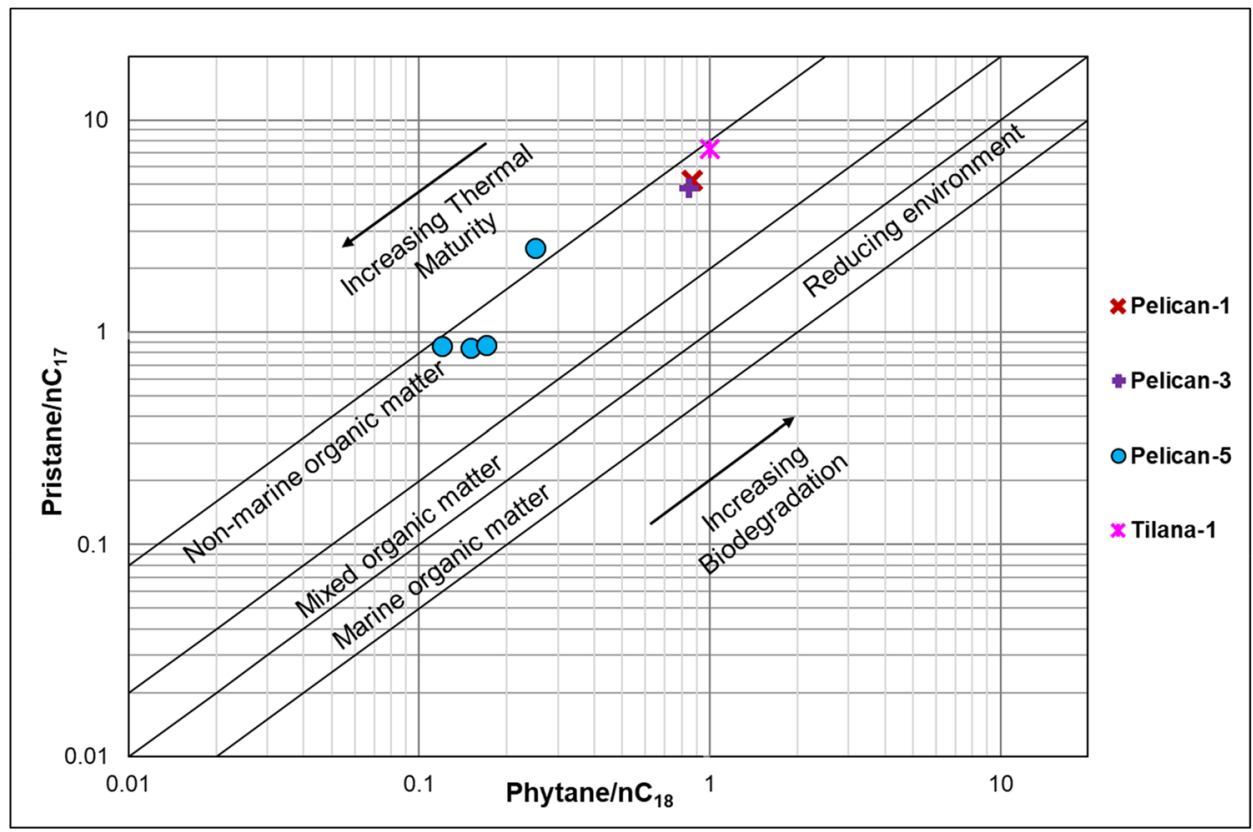


Fig. 15 Ternary diagram of the regular steranes $\mathrm{C}_{27}, \mathrm{C}_{28}$ and $\mathrm{C}_{29}$ for paleodepositional environment of the Narimba Formation (modified from Huang and Meinschein 1979)
Fig. 16 Paleodepositional environment by plotting $\mathrm{C}_{27}$ / $\left(\mathrm{C}_{27}+\mathrm{C}_{29}\right)$ sterane versus $\mathrm{Pr} / \mathrm{Ph}$ (modified from Hossain et al. 2009)
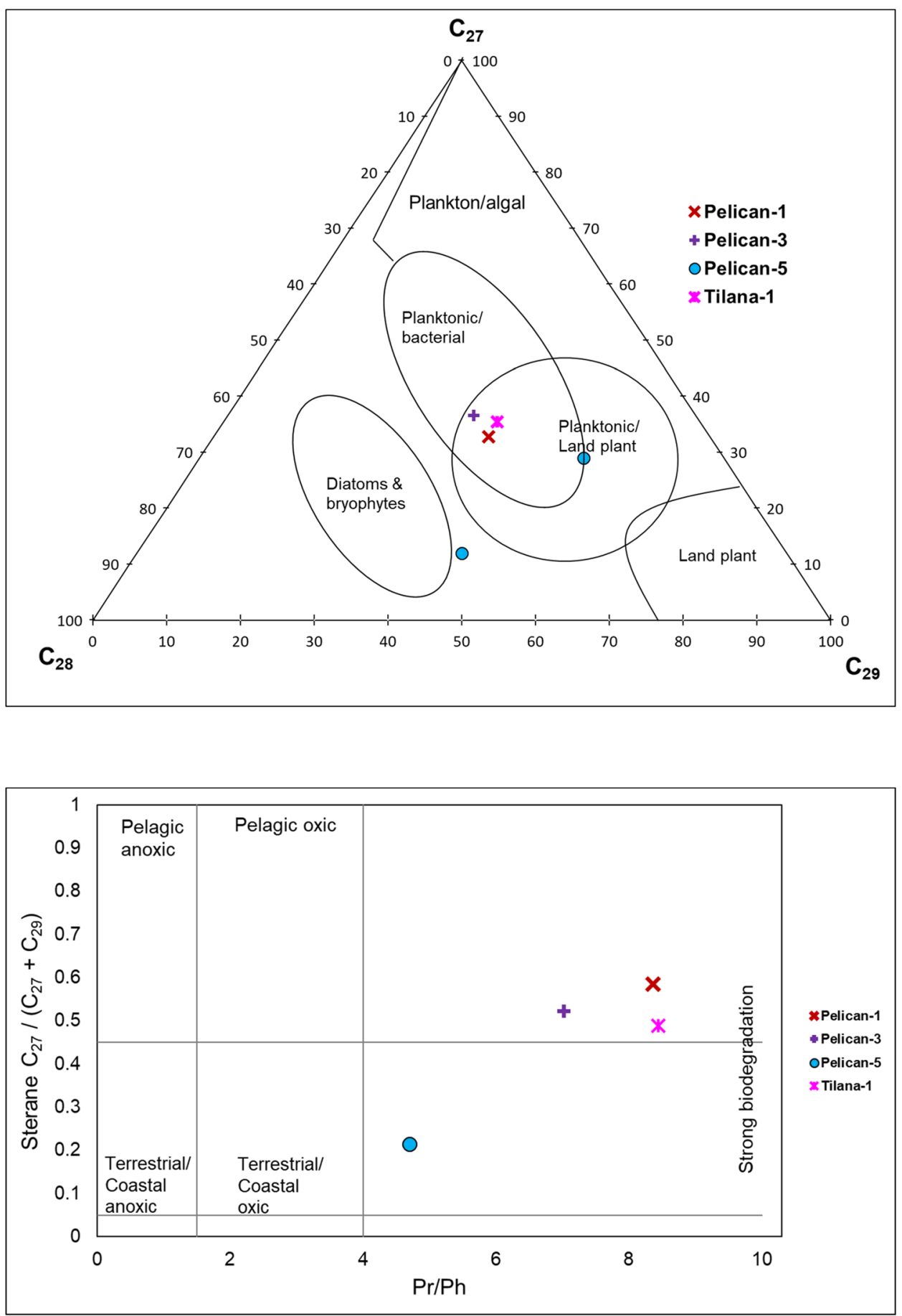

observed in Fig. 13a, b. The modes are around $\mathrm{nC}_{13}, \mathrm{nC}_{17}$ and $\mathrm{nC}_{27}$ for both figures. Meanwhile, the n-alkane distributions of chromatograms in Fig. 13c, d are unimodal, with modes at $\mathrm{nC}_{17}$ and $\mathrm{nC}_{25}$, respectively. The presence of lower and higher molecular weight compounds from all the chromatograms, especially in Fig. 13a, b, suggests the contribution of both algal (marine) and terrigenous organic matter, respectively. In Fig. 13c, there is dominance of intermediate molecular weight compounds indicating a higher algal influence. Contrastingly, Fig. 13d shows a dominance of higher molecular weight compounds and, hence, indicates a stronger influence of terrestrial environment. Such conclusions of the depositional environment are consistent with results observed in Figs. 14, 15, 16, 17.

$\mathrm{Pr} / \mathrm{Ph}$ which is the ratio between the two biomarker isoprenoids pristane $(2,6,10,14$-tetramethyl pentadecane) and phytane $(2,6,10,14$-tetra-methyl hexadecane) can be utilized to evaluate the conditions of a source rock's 
Fig. 17 Further support for paleodepositional environment by plot of $\mathrm{C}_{27} / \mathrm{C}_{29}$ regular sterane versus $\mathrm{Pr} / \mathrm{Ph}$

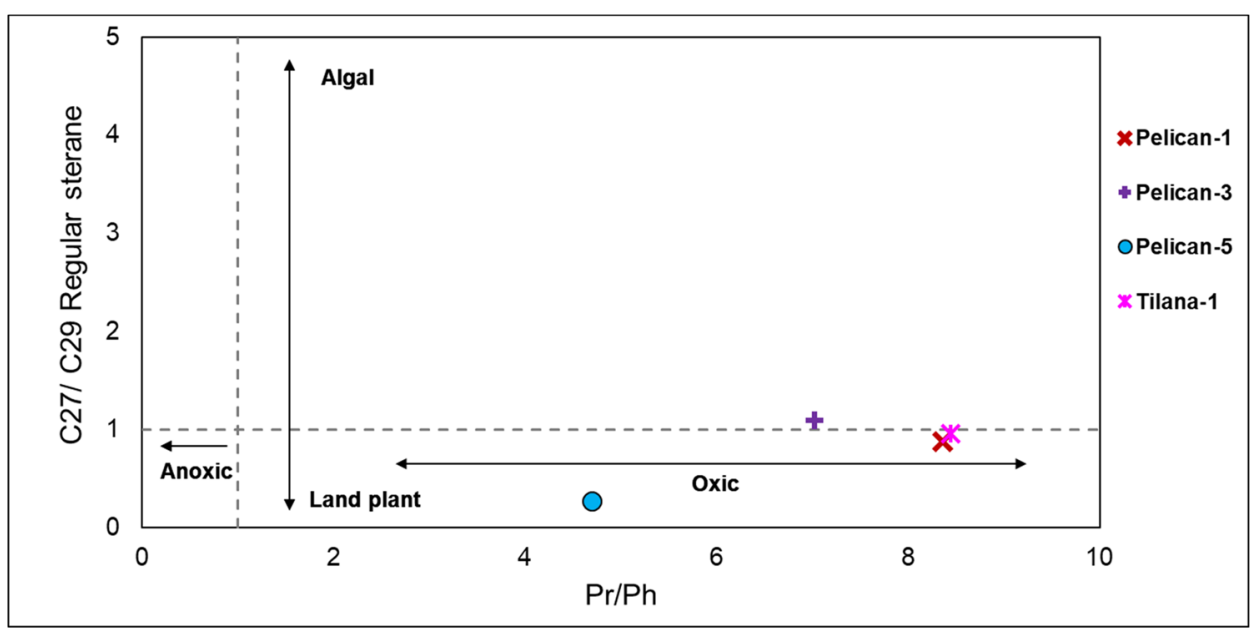

depositional environment (Peters et al. 2005; Moustafa and Morsi 2012). $\mathrm{Pr} / \mathrm{Ph}$ ratios in addition to the isoprenoids/nalkanes ratios can indicate the paleodepositional environments subjected to the source rock at the time of deposition (Powell and McKirdy 1973; Didyk 1978). According to the data displayed in Table 4, the isoprenoids/n-alkanes ratios used in this study are the $\mathrm{Pr} / \mathrm{nC}_{17}$ and $\mathrm{Ph} / \mathrm{nC}_{18}$ ratios (Table 4). These two parameters indicate biodegradation, maturation and diagenetic state of a source rock (Peters et al. 2005; Jumat et al. 2018; Osli et al. 2019). Correlation of the two ratios by cross-plot can define the paleodepositional environment of the Narimba Formation (Peters et al. 2005). This is shown in Fig. 14 which indicates the dominance of non-marine organic matter (oxidizing environment). This has been confirmed later when evaluating the $\mathrm{Pr} / \mathrm{Ph}$ values among the analyzed samples from different wells. It has been found that $\mathrm{Pr} / \mathrm{Ph}$ values range from 1.30 to 10.18 which are much higher than 1 and also suggest an oxygen-rich depositional environment with a dominance of terrestrial plant sources. This is in good agreement with interpretation made previously by isoprenoids/n-alkanes. Significant biodegradation is also evident in the plots (Fig. 14) of samples from Pelican-1, Pelican-3 and Tilana-1.

The regular sterane biomarkers $\mathrm{C}_{27}, \mathrm{C}_{28}$ and $\mathrm{C}_{29}$ (Table 5) were also used in this study to indicate the environmental origin of the organic matter making up the hydrocarbon. Generally, a dominance in the concentration of $\mathrm{C}_{27}$ steranes would signify marine origin, dominance of $\mathrm{C}_{28}$ points to lacustrine environment particularly algal, and dominance of $\mathrm{C}_{29}$ indicates terrestrial origin. These parameters can be used in correlation by using a ternary diagram as shown in Fig. 15 (Huang and Meinschein 1979). The figure shows that the $\mathrm{C}_{29}$ sterane has the strongest influence. However, data points suggest that the paleodepositional environment is marginal between terrestrial and marine with Pelican-5 having most dominant terrestrial origin.
In Fig. 16, a plot of $\mathrm{C}_{27} /\left(\mathrm{C}_{27}+\mathrm{C}_{29}\right)$ sterane versus the isoprenoids $\mathrm{Pr} / \mathrm{Ph}$ had been used to further describe paleodepositional environment (Hossain et al. 2009). In the figure, all samples show oxic environment origins where Pelican-1, Pelican-3 and Tilana- 1 samples are intermediate between terrestrial and marine origin and the Pelican-5 sample is terrestrial. There are also indications of strong biodegradation according to Pelican-1, Pelican-3 and Tilana-1 samples. This is in good compliance with Figs. 13 and 14. Deductions are further supported in Fig. 17 where the cross-plot of $\mathrm{C}_{27} / \mathrm{C}_{29}$ versus $\mathrm{Pr} /$ $\mathrm{Ph}$ shows oxic depositional conditions with the influence of both land and marine environments. Pelican-5 is also again shown to have the highest terrestrial influence. Biodegradation signatures apparent in the gas chromatograms (Fig. 13) provide added confidence in the interpretations of levels of biodegradation in Figs. 14 and 16. Biodegradation removes n-alkanes (lower members) first since they are more easily destroyed by bacteria. This can be observed in Fig. 13a, b and $\mathrm{d}$ where the absence of lower-member n-alkanes produces an irregular pattern at the base of the sample signatures.

\section{Conclusions}

The geochemical analysis and source rock characteristics of the Narimba Formation within the Bass Basin possess excellent potential as a promising source rock. Based on pyrolysis data, high TOC values indicated good to excellent organic richness. According to pyrolysis parameters ( $S 2$ and $\mathrm{HI}$ ), maceral compositions and gas chromatograms, the source rocks have fair to excellent quality, primarily and most abundance, consisting of Type III, Type II/III and Type II (gas, mixed and oil-prone, respectively). The source rocks are thermally mature, dominantly in the oil and oil/gas window, as indicated by Tmax and vitrinite reflectance values as well as gas chromatograms. Biomarker data and derivatives indicated that the

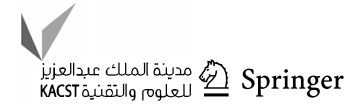


paleodepositional environment of the Narimba Formation is dominantly marginal between terrestrial and marine. Pelican-5 samples, particularly, showed the strongest terrestrial influence compared to samples from other wells. Furthermore, the rock samples did not show signs of significant migration of hydrocarbons as longer-chained atoms are still majorly unbroken according to the gas chromatograms.

Acknowledgements The authors are very grateful to the Government of Western Australia, Department of Mines, Industry Regulation and Safety, for allowing the complete dataset available online for research and teaching usage. Last but not least, sincere gratitude is also extended to the Universiti Brunei Darussalam for providing assistance and support in completing this research.

\section{Compliance with ethical standards}

Conflict of interest On behalf of all the co-authors, the corresponding author states that there is no conflict of interest.

Open Access This article is licensed under a Creative Commons Attribution 4.0 International License, which permits use, sharing, adaptation, distribution and reproduction in any medium or format, as long as you give appropriate credit to the original author(s) and the source, provide a link to the Creative Commons licence, and indicate if changes were made. The images or other third party material in this article are included in the article's Creative Commons licence, unless indicated otherwise in a credit line to the material. If material is not included in the article's Creative Commons licence and your intended use is not permitted by statutory regulation or exceeds the permitted use, you will need to obtain permission directly from the copyright holder. To view a copy of this licence, visit http://creativecommons.org/licenses/by/4.0/.

\section{References}

Arian N (2010) Hydrocarbon potential of Eastern View Group reservoir rocks, Bass Basin, Australia, pp 1-15(PhD thesis, Australian School of Petroleum, Faculty of Engineering, Computer and Mathematical Sciences, University of Adelaide, Australia)

Ayinla HA, Abdullah WH, Makeen YM, Abubakar MB, Jauro A, Yandoka BMS, Mustapha KA, Abidin NSZ (2017) Source rock characteristics, depositional setting and hydrocarbon generation potential of Cretaceous coals and organic rich mudstones from Gombe Formation, Gongola sub-basin, Northern Benue Trough, NE Nigeria. Int J Coal Geol 173:212-226. https://doi.org/10.1016/j. coal.2017.02.011

Baillie PW, Pickering R (1991) Tectonic evolution of the Durroon Basin Tasmania. Explor Geophys 22(1):13-18. https://doi. org/10.1071/EG991013

Barker C (1974) Pyrolysis techniques for source-rock evaluation. AAPG Bull 58(11):2349-2361. https://doi.org/10.1306/83D91 BAF-16C7-11D7-8645000102C1865D

Blevin JE, Boreham CJ, Trigg KR, Cummings A, Daniel R, Kaldi J, Lang SC, Lemon N, Root R, Tingate P, Alan D, Partridge AD (2003) (2003) Petroleum geology of the Bass Basin-Interpretation report: an output of the Western Tasmanian Regional Minerals Program. Geosci Aust Rec 19:1-263
Blevin JE, Trigg KR, Partridge AD, Boreham CJ, Lang SC (2005) Tectono-stratigraphy and potential source rocks of the Bass Basin. APPEA J 45(1):601-622. https://doi.org/10.1071/AJ040 45

Boreham CJ, Summons RE (1999) New insights into the active petroleum systems in the Cooper and Eromanga basins, Australia. APPEA J 39(1):263-296

Boreham CJ, Blevin JE, Radlisnki AP, Trigg KR (2003) Coal as a source of oil and gas: a case study from the Bass Basin, Australia. APPEA J 43(1):117-148. https://doi.org/10.1071/AJ02006

Cummings AM, Hillis RR, Tingate PR (2004) New perspectives on the structural evolution of the Bass Basin: Implications for petroleum prospectivity. In: Paper presented at the PESA eastern Australasian Basins Symposium II, 19-22nd November, Adelaide, Australia, pp 133-149

Didyk BM (1978) Organic geochemical indicators of palaeoenvironmental conditions of sedimentation. Nature 272:216-222. https:// doi.org/10.1038/272216a0

Edwards DS, Struckmeyer HIM, Bradshaw MT, Skinner JE (1999) Geochemical characteristics of Australia's southern margin petroleum systems. APPEA J 39(1):297-321. https://doi.org/10.1071/ AJ98017

Espitalié J (1986) Use of Tmax as a maturation index for different types of organic matter. In: Burrus J (ed) Thermal Modelling in Sedimentary Basins. Editions Technip - Paris, France, pp 475-496. https://doi.org/10.1180/claymin.2010.045.1.115

Espitalié J, Madec M, Tissot B, Mennig JJ, Leplat P (1977) Source rock characterization method for petroleum exploration. In: Paper presented at the offshore technology conference, 2-5th May, Houston, Texas. https://doi.org/10.4043/2935-MS

Espitalié J, Deroo G, Marquis F (1985) Rock-Eval pyrolysis and its applications. Revue De L InstitutFrancais Du Petrole 40(5):563579. https://doi.org/10.2516/ogst: 1986003

Etheridge MA, Branson JC, Stuart-Smith PG (1985a) Extensional basin-forming structures in Bass Strait and their importance for hydrocarbon exploration. APPEA J 25(1):344-361. https://doi. org/10.1071/AJ84030

Etheridge MA, Branson JC, Falvey DA, Lockwood KL, Stuart-Smith PG, Scherl AS (1985b) Basin-forming structures and their relevance to hydrocarbon exploration in Bass Basin, southeastern Australia. J Aust Geol Geophys 9:197-206

Fakhri M, Tabatabaei H, Amiri A (2013) Comparing the potential of hydrocarbon generation of Kazhdomi and Pabdeh Formations in Bangestan Anticline (Zagros Basin) according to Rock-Eval pyrolysis data. J Earth Sci Clim Change 4(5):157(1-7). https:// doi.org/10.4172/2157-7617.1000157

Hossain HZ, Sampei Y, Roser BP (2009) Characterization of organic matter and depositional environment of tertiary mudstones from the Sylhet Basin, Bangladesh. Organ Geochem 40(7):743-754. https://doi.org/10.1016/j.orggeochem.2009.04.009

Huang WY, Meinschein WG (1979) Sterols as ecological indicators. Geochim Cosmochim Acta 43(5):739-745. https://doi. org/10.1016/0016-7037(79)90257-6

Jumat N, Shalaby MR, Islam MA (2017) An integrated source rock characterization using geochemical analysis and well logs: a case study of Taranaki Basin, New Zealand. Pet Coal 59(6):884-910

Jumat N, Shalaby MR, Haque AE, Islam MA, Hoon LL (2018) Geochemical characteristics, depositional environment and hydrocarbon generation modeling of the upper cretaceous Pakawau group in Taranaki Basin, New Zealand. J Pet Sci Eng 163:320-339. https ://doi.org/10.1016/j.petrol.2017.12.088

Langford FF, Blanc-Valleron MM (1990) Interpreting Rock-Eval pyrolysis data using graphs of pyrolizable hydrocarbons vs. total organic carbon (1). AAPG Bull 74(6):799-804 
Law CA (1999) Evaluating source rocks. In: Beaumont EA, Foster NH (eds) Treatise petroleum geology/handbook of petroleum geology: exploring for oil and gas traps. American Association of Petroleum Geologists, Oklahoma, USA, pp 6-41

Lennon RG, Suttill RJ, Guthrie DA, Waldron AR (1999) The renewed search for oil and gas in the Bass Basin: results of Yolla-2 and White Ibis-1. APPEA J 39(1):248-262. https://doi.org/10.1071/ AJ98015

Meszoly GFJ, Bodard JM, Wall VJ (1985) Diagenesis and porosity in the Eastern View Group, Bass Basin. In: Paper presented at the second south-eastern Australia Oil Exploration Symposium, PESA, 14-15 November, Melbourne, Australia, pp 303-315

Miyazaki S (1995) Oil generation from coals and carbonaceous claystones in the Bass Basin. PESA J 23:91-100

Mobarakabad AF, Bechtel A, Gratzer R, Mohsenian E, Sachsenhofer RF (2011) Geochemistry and origin of crude oils and condensates from the Central Persian Gulf. Offshore Iran. J Pet Geol 34(3):261-275. https://doi.org/10.1111/j.1747-5457.2011.00505.x

Moustafa YM, Morsi RE (2012) Biomarkers. In: Dhanarasu S (ed) Chromatography and its applications. InTechOpen, LondonRijeka, pp 165-186. https://doi.org/10.5772/35750

Mukhopadhyay PK (1994) Petrographic and molecular characterization and its applications to basin modeling. In: Mukhopadhyay PK, Dow WG (eds) Vitrinite reflectance as a maturity parameter: applications and limitations. American Chemical Society, Washington DC, USA, pp 1-24

Mukhopadhyay PK, Hatcher PG (1993) Composition of coal. In: Law BE, Rice DD (eds) Hydrocarbons from coal, American association of petroleum geologists studies in geology, vol 38. American Association of Petroleum Geologists, Oklahoma, USA, pp 79-118

Newman J (1997) New approaches to detection and correction of suppressed vitrinite reflectance. APPEA J 37(1):524-535

Newman J, Eckersley KM, Francis DA, Moore NA (2000) Application of vitrinite-inertinite reflectance and fluorescence to maturity assessment in the East Coast and Canterbury Basins of New Zealand. In: Proceedings of New Zealand Petroleum conference pp 314-333

Nicholas E, Lockwood KL, Martin AR, Jackson KS (1981) Petroleum potential of the Bass Basin. J Aust Geol Geophys 6:199-212

Osli LN, Shalaby MR, Islam MA (2018) Characterization of source rocks and depositional environment, and hydrocarbon generation modelling of the Cretaceous Hoiho formation, Great South Basin, New Zealand. Pet Coal 60(2):255-275

Osli LN, Shalaby MR, Islam MA (2019) Hydrocarbon generation modeling and source rock characterization of the CretaceousPaleocene Taratu Formation, Great South Basin, New Zealand. J Pet Explor Prod Technol 9(1):125-139

Partridge AD (2002) Bass Basin palynology project, unraveling a late Cretaceous to Eocene geological history of large palaeo lakes, coastal lagoons and marine bays. Biostrata Pty. Ltd., Biostrata Report 2002/13, pp 1-36

Peters KE (1986) Guidelines for evaluating petroleum source rock using programmed pyrolysis. AAPG Bull 70(3):318-329. https ://doi.org/10.1306/94885688-1704-11D7-8645000102C1865D

Peters KE, Moldowan JM (1993) The biomarker guide, interpreting molecular fossils in petroleum and ancient sediments. Prentice Hall, New Jersey, p 363

Peters KE, Cassa MR (1994) Applied source rock geochemistry. In: Magoon LB, Dow WG (eds) The petroleum system - from source to trap, AAPG Memoir, vol 60. American Association of Petroleum Geologists, Oklahoma, USA, pp 93-120

Peters K, Walters C, Moldowan J (2005) The biomarker guide, volume 2: biomarkers and isotopes in petroleum exploration and Earth history. Cambridge University Press, Cambridge, UK
Philp RP, Lewis CA (1987) Organic geochemistry of biomarkers. Annu Rev Earth Planet Sci 15(1):363-395. https://doi.org/10.1146/ annurev.ea.15.050187.002051

Powell TG, McKirdy DM (1973) Relationship between ratio of pristane to phytane, crude oil composition and geological environment in Australia. Nat Phys Sci 243(124):37-39. https://doi.org/10.1038/ physci243037a0

Qadri ST, Shalaby MR, Islam MA, Hoon LL (2016) Source rock characterization and hydrocarbon generation modeling of the Middle to Late Eocene Mangahewa Formation in Taranaki Basin, New Zealand. Arab J Geosci 9(10):559(1-17). https://doi.org/10.1007/ s12517-016-2586-4

Rodriguez ND, Philp RP (2015) Source rock facies distribution predicted from oil geochemistry in the Central Sumatra Basin, Indonesia. AAPG Bull 99(11):2005-2022. https://doi. org/10.1306/06191514050

Shalaby MR, Hakimi MH, Abdullah WH (2011) Geochemical characteristics and hydrocarbon generation modeling of the Jurassic source rocks in the Shoushan Basin, north western desert, Egypt. Mar Pet Geol 28(9):1611-1624. https://doi.org/10.1016/j.marpe tgeo.2011.07.003

Shalaby MR, Hakimi MH, Abdullah WH (2012a) Modeling of gas generation from the Alam El-Bueib formation in the Shoushan Basin, northern Western Desert of Egypt. Int J Earth Sci 102(1):319332. https://doi.org/10.1007/s00531-012-0793-0

Shalaby MR, Hakimi MH, Abdullah WH (2012b) Organic geochemical characteristics and interpreted depositional environment of the Khatatba formation, northern western desert, Egypt. AAPG Bull 96(11):2019-2036. https://doi.org/10.1306/04181211178

Shalaby MR, Hakimi MH, Abdullah WH (2012c) Geochemical characterization of solid bitumen (migrabitumen) in the Jurassic sandstone reservoir of the Tut field, Shushan Basin, northern western desert of Egypt. Int J Coal Geol 100:26-39. https://doi. org/10.1016/j.coal.2012.06.001

Shalaby MR, Jumat N, Lai D, Malik OA (2019a) Integrated TOC prediction and source rock characterization using machine learning, well logs and geochemical analysis: case study from the Jurassic source rocks in Shams Field, NW Desert, Egypt. J Pet Sci Eng 176(2019):369-380

Shalaby MR, Osli LN, Kalaitzidis S, Islam MA (2019b) Thermal maturity and depositional palaeoenvironments of the CretaceousPalaeocene source rock Taratu formation, Great South Basin, New Zealand. J Pet Sci Eng 181(2019): 106156

Shalaby MR, Malik OA, Lai D, Jumat N, Islam MA (2020) Thermal maturity and TOC prediction using machine learning techniques: case study from the Cretaceous-Paleocene source rock, Taranaki Basin, New Zealand. Petrol Explor Prod Technol. https://doi. org/10.1007/s13202-020-00906-4

Simoneit BRT (2002) Molecular indicators (biomarkers) of past life. Anat Rec 268(3):186-195. https://doi.org/10.1002/ar.10153

Tissot BP, Welte DH (1978) Petroleum formation and occurrence: a new approach to oil and gas exploration. Springer-Verlag, Berlin

Waples DW (1985) Geochemistry in petroleum exploration. D. Reidel Publishing Co., Dordrecht-Boston-Lancaster, pp 1-232

Wilkins RWT, George SC (2002) Coal as a source rock for oil: a review. Int J Coal Geol 50(1-4):317-361. https://doi.org/10.1016/ S0166-5162(02)00134-9

Publisher's Note Springer Nature remains neutral with regard to jurisdictional claims in published maps and institutional affiliations. 